المركة الظاهرية كموثر تفاعلى لإثراء الروية البمالية للومة

\title{
الزخرفية المبسمة
}

\author{
أ.م.د / هشام محمد أمين السرسي لهري
}

استاذ التصميم المساعد بقسم التربية الفنية

كلية التربية النوعية- جامعة المنوفية

ملخص:

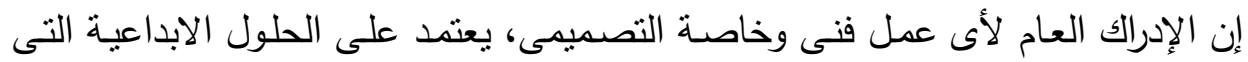

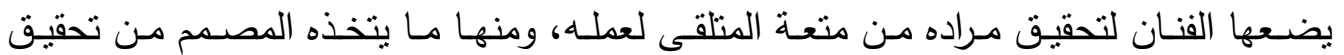

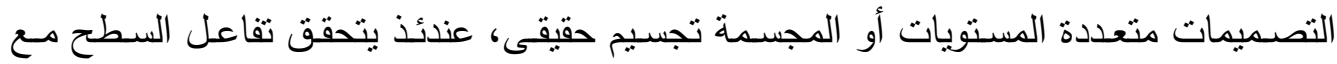
الفراغ الحقيقي، ولا يتم ذلك إلا في وجود مـا يُشكل على السطح ويتكون أعـلاه، فيصنع ذلك

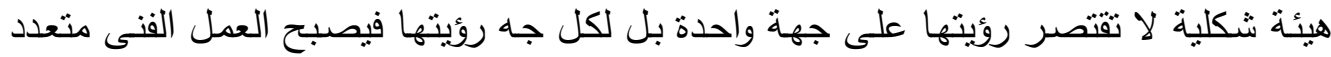

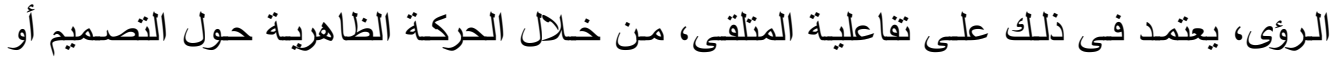

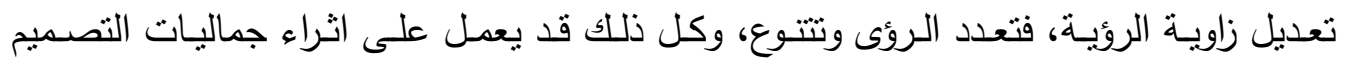

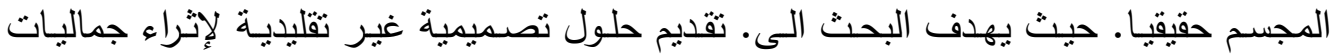

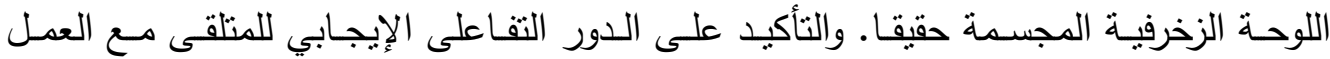
التصميمى. والتأكيد على نوع غير متداول من الحركة فى مجال التصميم وهى الحركة الظاهربة التهية

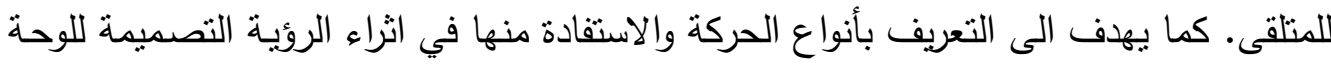
الزخرفية المجسمة. والتأكيد على تفعيل دور المتلقى لتنوع الرؤى التصميمة من خلال المشاركة

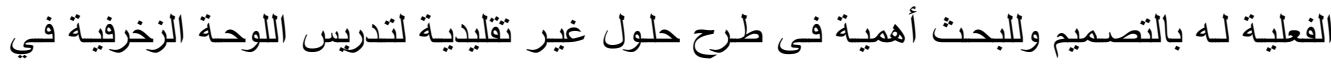

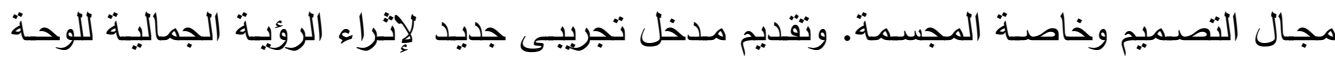
الزخرفية المجسمة. والكثف عن فاعلية توظيف البعد الثالث الحقيقى تصميميا. والقاء الضوء على دور المتلقى في تحقيق ثراء الروئة التصميمية في اللوحة الزخرفية المجسمة وتهية

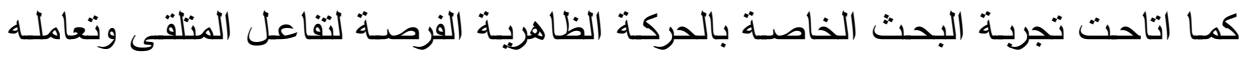
بايجابية مـع العمل التصميمى. كما حققت الحركة الظاهرية ثراء في تتوع الرؤيسة وبالتالى القيم الجمالية للعمل من خلال المتغيرات الشكلية للعمل التصميمى ـ واتاحت التصميمات المجسمة

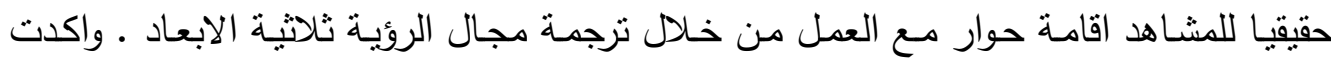
التصـميمات القائمسة على الحركـة الظاهربـة للمشـاهد على الفكـر المعاصـرة والمفـاهيم الحديثة للتجريب في الفن. واشـارت الى ان الفن المعتمد على التفاعل بين المشـاهد والعمل الفنى يخرج المتلقى من حالة الجمود في الرؤيسة الحى التفاعل والمعايشــة والمشـاركة ـ والأعمـال التصـيمية التفاعلية تنقل المشاهد ليصبح منلقى ومتذوق.

الكلمات المفتاحية: الحركة الظاهرية، الروئية الجمالية اللوحة الزخرفية المجسمة. 


\section{Summary of the research}

\section{Title : The virtual movement as an interactive effect to enrich the aesthetic vision of the stereoscopic decorative panel}

The general perception of any artistic work, especially the design, depends on the creative solutions that the artist puts in place to achieve his goal of the recipient's enjoyment of his work, including what the designer takes to achieve multi-level designs or stereoscopic designs, a true embodiment, then the interaction of the surface with the real void is achieved, and this is only done in The presence of what is formed on the surface and formed above, thus making a formal body whose vision is not limited to one side, but to each side its vision, so the artwork becomes multi-visions, depending on the interaction of the recipient, through the apparent movement around the design or modifying the angle of vision, so the visions are multiplicity and varied, And all of this may enrich the aesthetics of the real stereoscopic design. Where the research aims to. Providing unconventional design solutions to truly enrich the aesthetics of stereoscopic decorative painting. Emphasis on the positive interactive role of the recipient with the design work. Emphasis on a non-current type of movement in the field of design, which is the virtual movement of the recipient. It also aims to introduce the types of movement and benefit from them in enriching the design vision of the stereoscopic decorative panel. Emphasis on activating the role of the recipient of the diversity of design visions through his actual participation in the design and the importance of research in offering non-traditional solutions for teaching decorative painting in the field of design, especially stereoscopic. And presenting a new experimental entrance to enrich the aesthetic vision of the stereoscopic decorative panel. And revealing the effectiveness of employing the real third dimension in design, and shedding light on the role of the recipient in achieving the richness of the design vision in the stereoscopic decorative painting.

The research experience of the virtual movement also provided the opportunity for the recipient to interact and deal positively with the design work. The virtual movement also achieved a richness in the diversity of vision and therefore the aesthetic values of the work through the formal variables of the design work. The stereoscopic designs allowed the viewer to establish a dialogue with the work by translating the field of view in three dimensions. The designs based on the virtual movement of the viewer emphasized contemporary thought and modern concepts of experimentation in art. She pointed out that art based on interaction between the viewer and the artwork brings the recipient out of a state of stagnation in vision to interaction, coexistence and participation. Interactive design works transport the viewer to become a recipient and connoisseur. 
إن الحركة كظاهرة طبيعية تعكس في ماهيتها الحياه، فهى سمة اله في فمعظم مخلوقاته نراها بشكل مباشر أو ندرك أثزها، والفنان كأى كائن من خلق اله بتصف باهئ بالحركة، ولكن الفنان

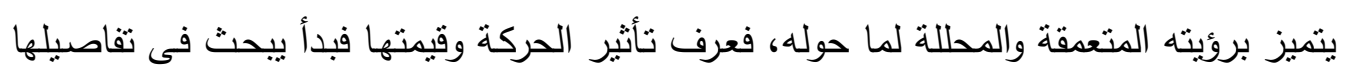
وأنواعها وطرق تحقيقها فى أعماله الفنية، حيث ظل الفنان التشكيلى يبحث عن الطرق ولئه والوسائل

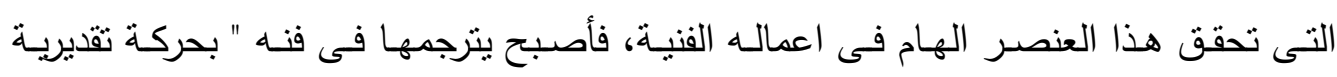
مسطحة ذات بعدين، وثالث إيهامى فى أول الامر ، وبذلك أصبح عنصر الحركة عنصرا هاما

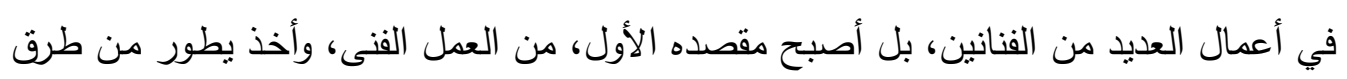

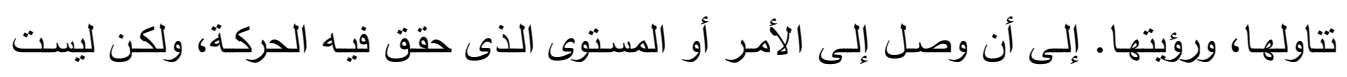
تقديريه، بل حركة فعلية، وبأنواع كثيرة، حيث يعتبر عنصر الحركة، أحد أهم ما يؤكد عليه لأهن

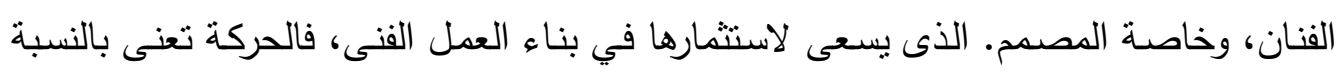

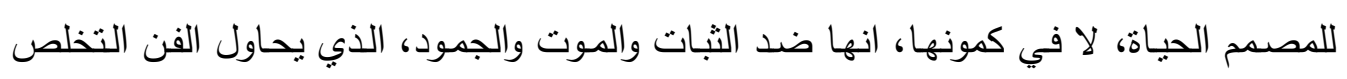

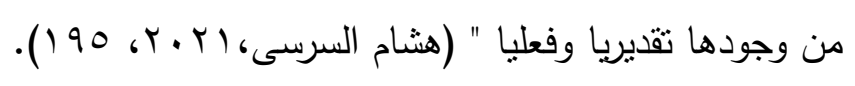

وفى بحث الفنان وتجريبه لإيجاد الحركة كعنصر فى العمل الفنى والتعبير عنها بفنه،

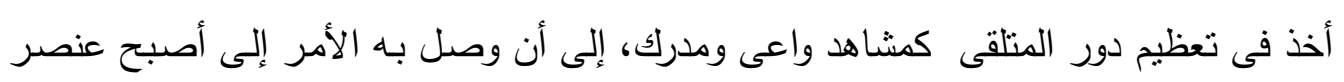

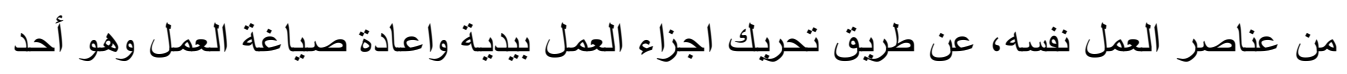

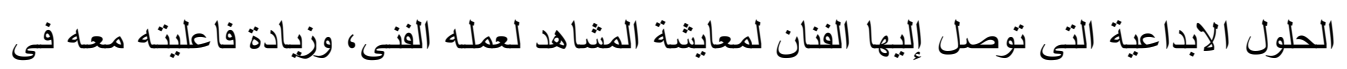

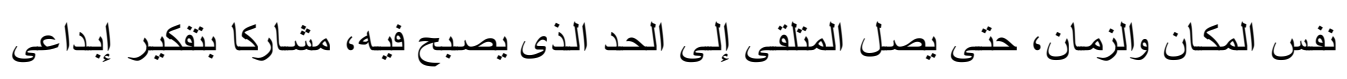

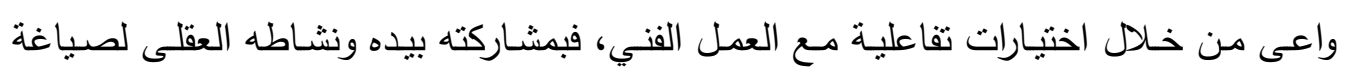

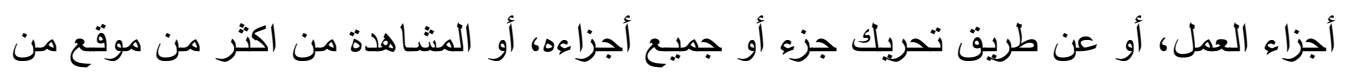
خلال تحرك المتلقى فعليا، أمام وحول العمل الفني، الأمر الذى يؤدى إلى اختلاف زواءيا رؤيته للعمل، وبهذا يصبح المتلقى جزءا لا يتجزأ من العمل نفسـه، ويصبح من أهم الأسس التى يبنى الهي

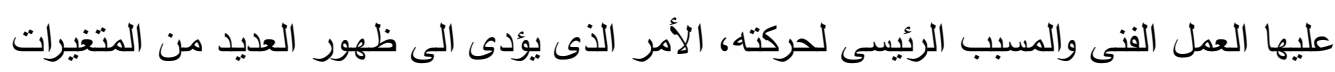

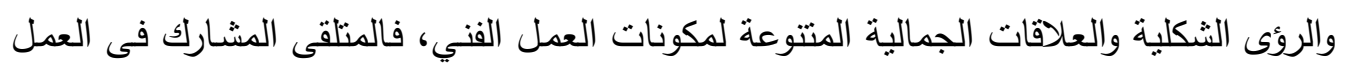
الفنى هو جزء من اللغة الفنية، يكتشف أسرارها عن طريق تفاعله، محققا بعدا جديدا هو الزمن. 
وكان من الضرورى لتحقيق فعلية الروية للعمل الفنى وثراء وتعدد مشـاهده، كان لابد من

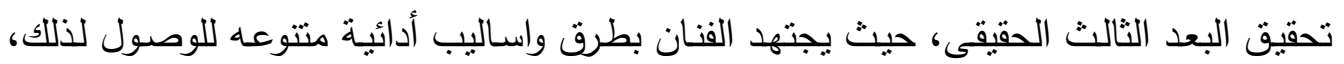
ويضيف أبعادا وقيما جمالية جديدة، حيث تشغل المجسمات وتعدد الاسطح، حيز من الفراغ

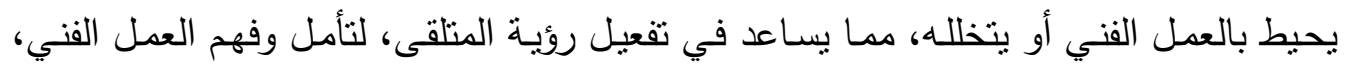

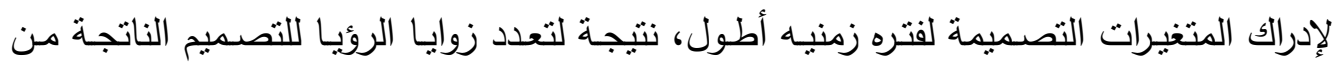

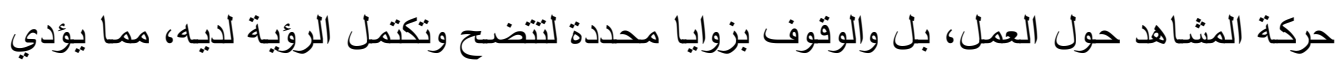

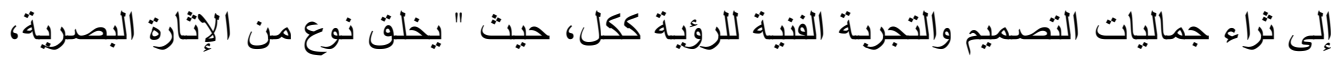

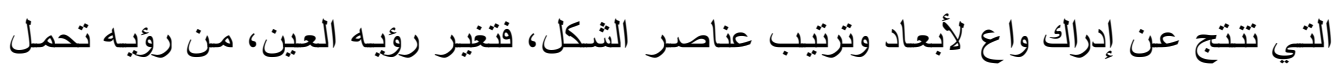

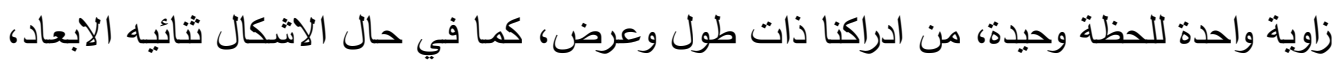

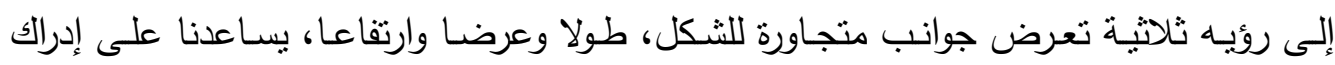

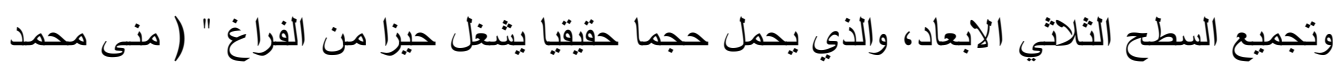

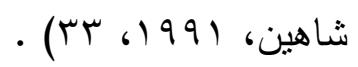

والباحث فى هذا البحث يؤكد على نوع من أنواع الحركة الفعلية، وهى الحركة وهى

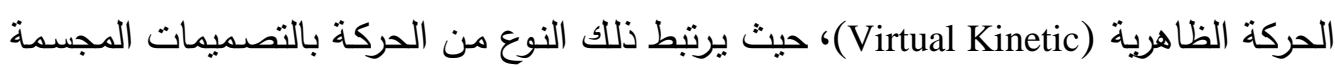

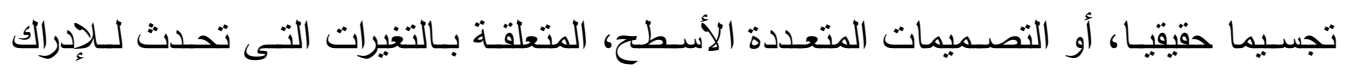

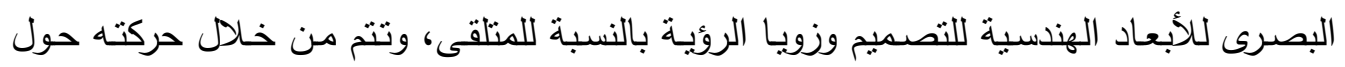

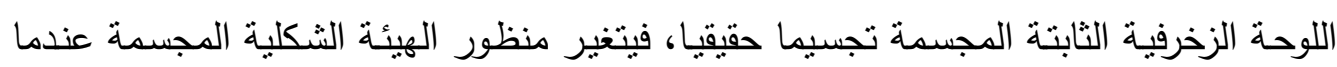
تتغير زاوية روية المتلقى للعمل الفنى.

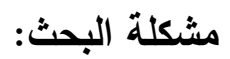

إن الإدراك العام لأى عمل فنى وخاصـة التصميمى، يعتمد على الحلول الابداعية التى

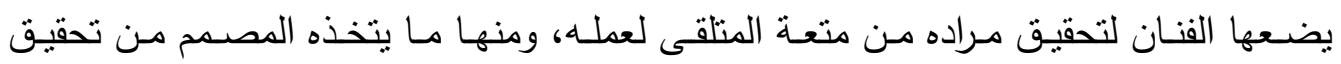

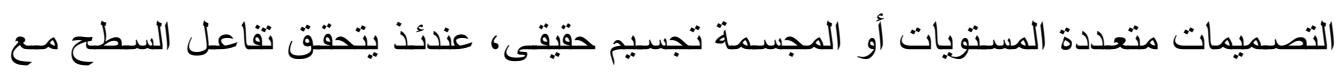

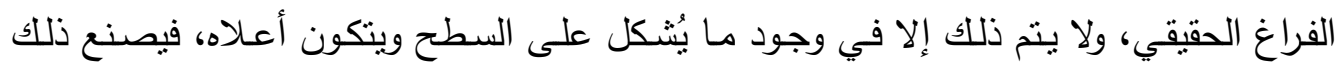
هيئة شكلية لا تقتصر رؤيتها على جهة واحدة بل لكل جها رؤيتها فيصبح العمل الفنى متعدد

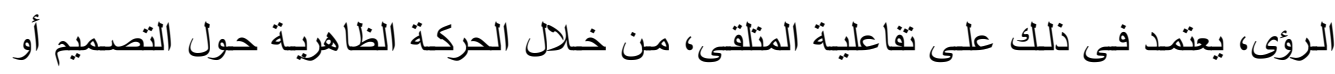
تعديل زاويـة الروئية، فتعدد الرؤى وتتتوع، وكل ذلك قلد يعمل على اثلى اثراء جماليـات التصميم 
• كيفية يمكن الاستفادة من الحركة الظاهرية لإثراء الروئية الجمالية للوحة الزخرفية المجسمة

حقيقيا ؟

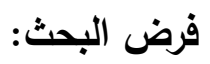

الحركة الظاهرية للمتلقى تثرى الروئية الجمالية للوحة الزخرفية المجسمة حقيقيا.

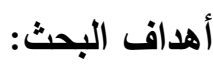

1- تقديم حلول تصميمية غير تقليدية لإثراء جماليات اللوحة الزخرفية المجسمة حقيقا.

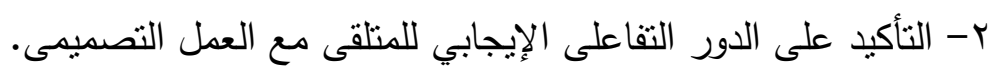

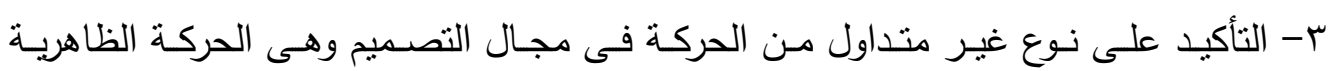
للمتلقى. ع- التعريف بأنواع الحركة والاستفادة منها في اثراء الروئة التصميمة للوحة الزخرفية المجسمة. ه- الخروج من تقليدية اللوحة الزخرفية المسطحة لصياغة مجسمة تجسيم حقيقى متعدد الرؤى.

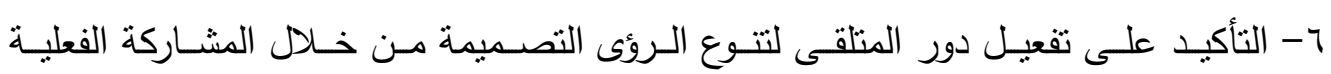
له بالتصميم

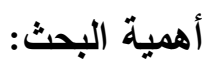

1- طرح حلول غير تقليدية لتدريس اللوحة الزخرفية في مجال التصميم وخاصة المجسمة. r- تقديم مدخل تجريبى جديد لإثراء الرؤية الجمالية للوحة الزخرفية المجسمة. r- الكثف عن فاعلية توظيف البعد الثالث الحقبقى تصميميا. ع- القـاء الضـوء على دور المتلقى في تحقيـق ثراء الرؤيـة التصـيمية في اللوحسة الزخرفيـة المجسمة.

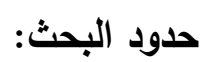
تقتصر اجراء التجربة التطبيقية للبحث على. ا- طـلاب الفرقة الثالثة بقسم التربيـة الفنية بكليـة التربيـة النوعيـة جامعـة المنوفيـة الترم الاول

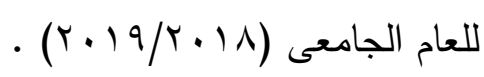


r- تصميم وتتفيذ عدد (r) من اللوحات الزخرفية على ورق الكانسون الابيض كخطوة تمهيدية لتنفيذ اللوحة الزخرفية المجسمة حقيقيا ـ التهد

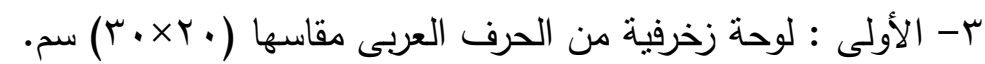

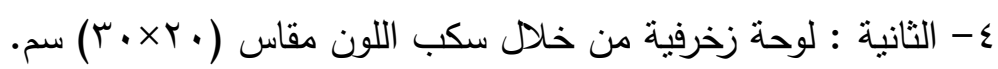
ه- تقتصر خامة اللون على ألوان الجواش (البوستر) . צ- تتفيذ لوحة زخرفية مجسمة حقيقيا من خلال الجمع بين اللوحة الزخرفية الأولى والثانية. منهجية البحث : يعتمد البحث علي المنهج الوصفي التحليلى والمنهج شبه التجريبي من خـلا الاطار

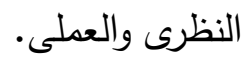
الاطار النظي: يتضمن هذا الاطار النقاط الاتية: 1- الحركة ودورها تصميميا. r- البعد الثالث الحقيقى كضرورة لفعلية حركة المتلقى.

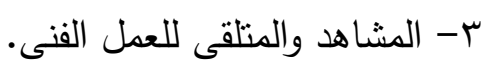

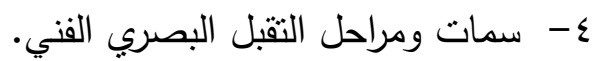
0- - خطوات الاستجابة الجمالية للعمل الفنى. 7- ديناميكية المتلقى وفاعلية الرؤية. V- الحركة الظاهرية للمتلقى وتعدد زوايا الروية. 1- الحركة الظاهرية (المنظور الحركى) فى التصميم. الاطار العملي : لـه

يعتمد الباحث فـى هذا الإطـار على توضيح أبعاد الجانب التطبيقى للتجربـة التطبيقيـة وخطوات تتفيذها، وتوصيف وتتظير نتائجها من خلا اللوحة الزخرفية المجسمة حقيقيا. 


\section{1- الحركة ودورها تصميميا .}

الحركة ظاهرة حياتية، ودائما ما يحاول المصمم جاهدا أن يصل الي تحقيق الحركة في

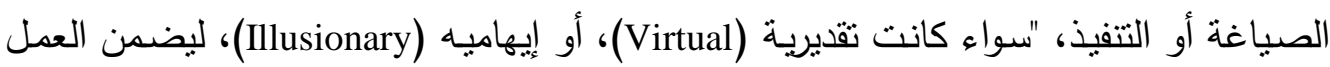

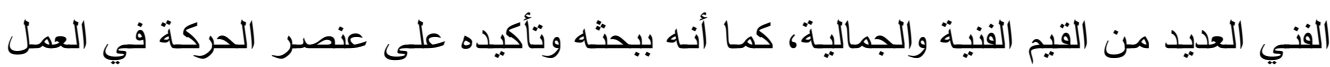
الفنى، يوظف البعد الرابع الذي تفققده الكثير من الأعمال الفنية وهو الزمن، ليعيد تأكيد العلاقة الئه

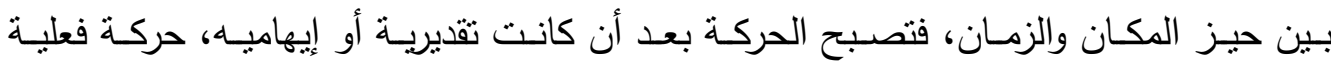

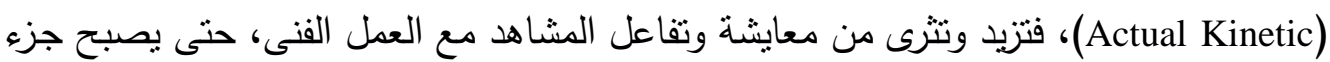

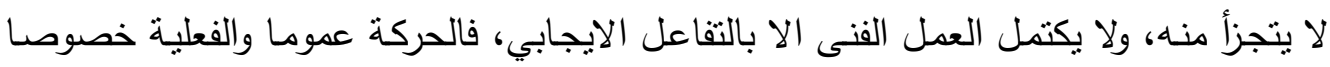

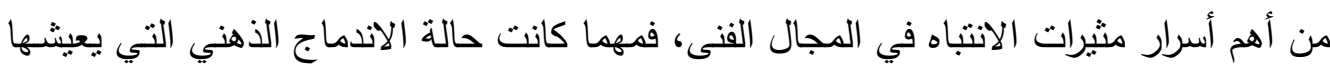

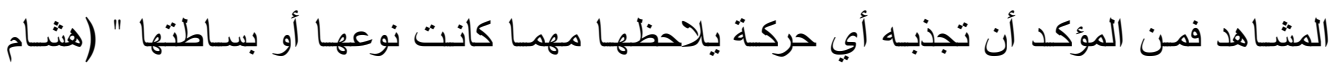

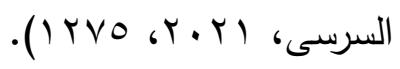

\section{r - البعد الثالث الحقيقى كضرورة لفعلية حركة المتلقى .}

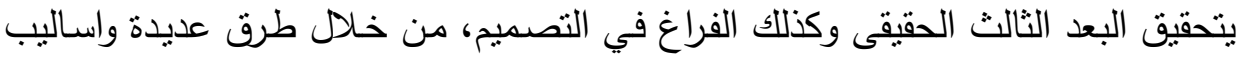

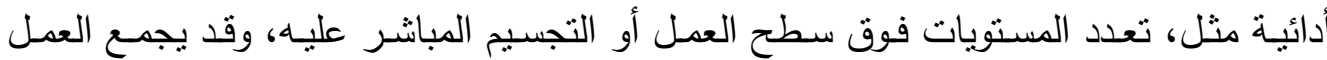

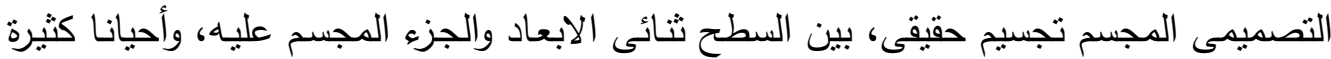

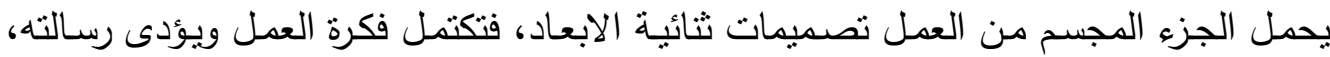

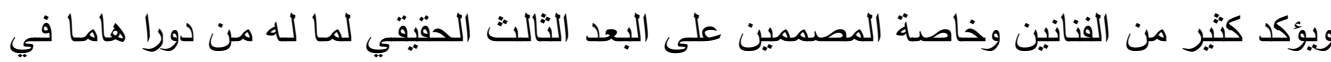

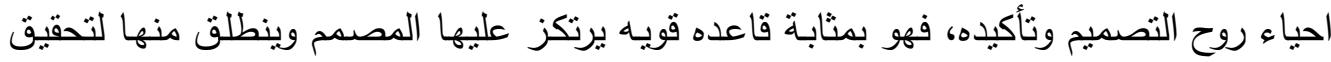

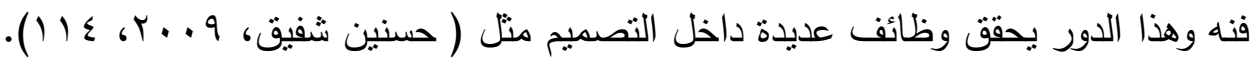
امداد العين براحه وتتظيم عمليه الادراك البصرى .

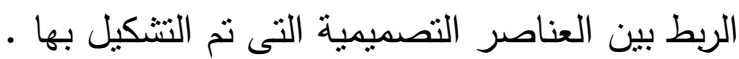

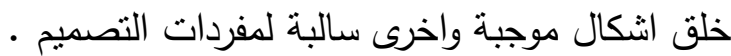

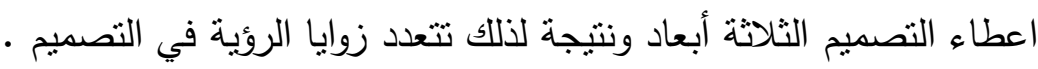

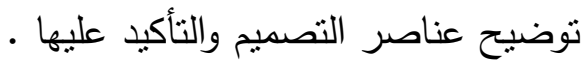

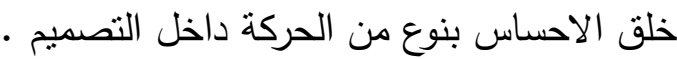
وقد يتحقيق البعد الثالث الحقيقي داخل التصميم من خـلال الاشكال الهندية متعددة

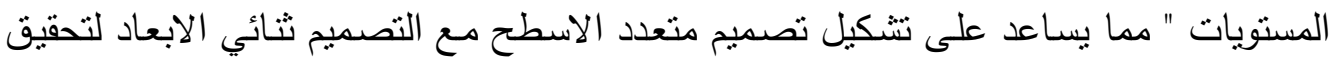


التوافق البصري والنظام مما يخلق اثارة بصرية تتتج عن إدرالك واع لأبعاد وترتيب عناصر

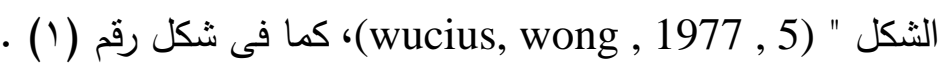
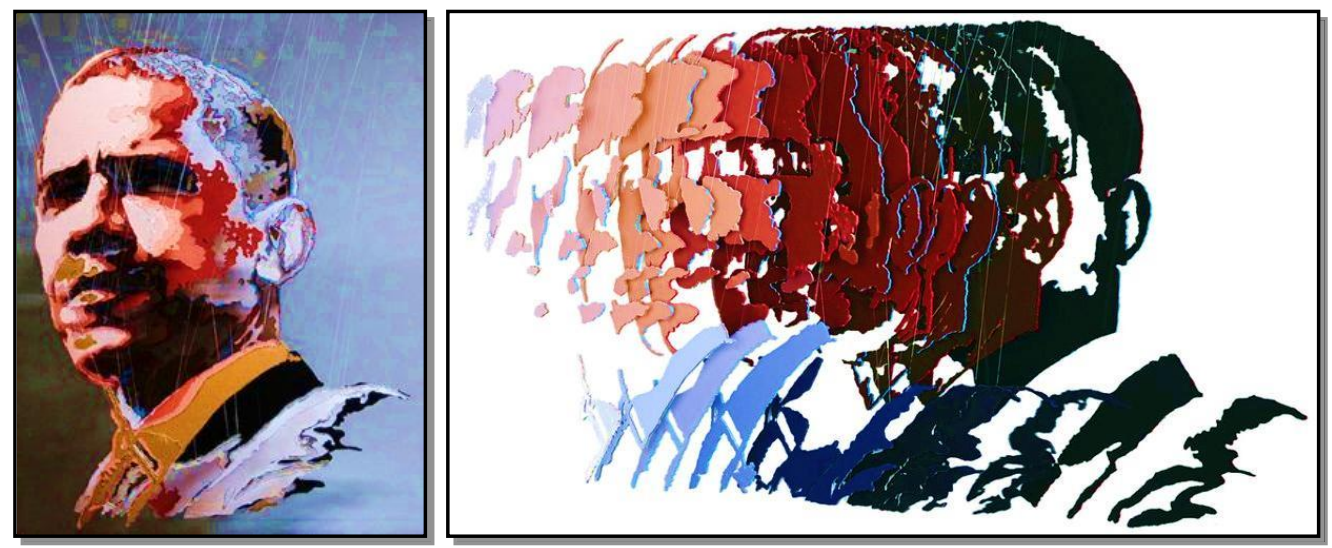

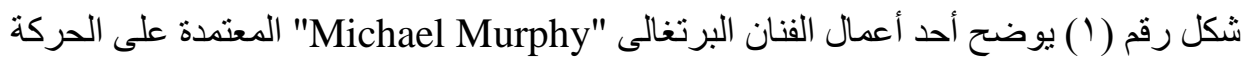
الظاهرية من خلال مشار كة المتلقى بتغيير زو الفية رؤيته المسببة لتعدد مشاهد التصميم، عن : /https://mymodernmet.com/michael-murphy-president-obama-sculpture

r- المشاهد والمتلقى للعمل الفنى • المعا.

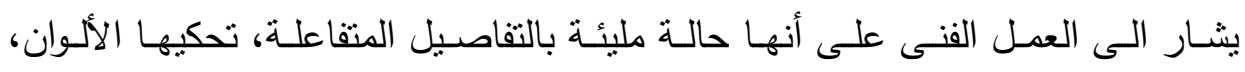

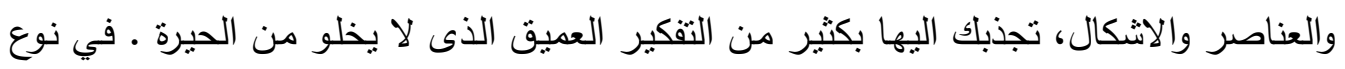

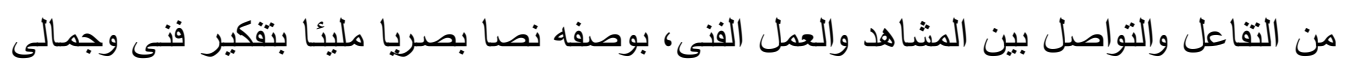

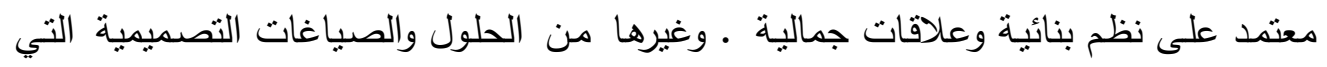

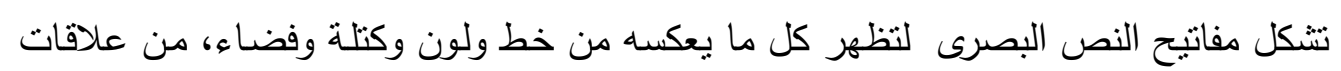

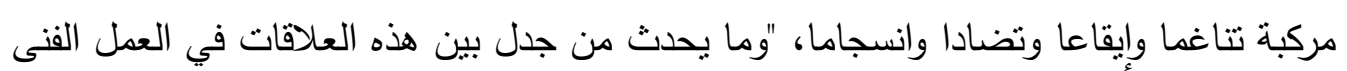

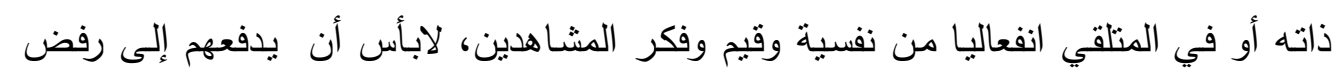

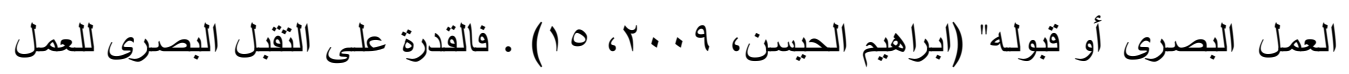

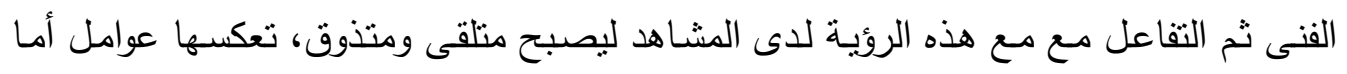

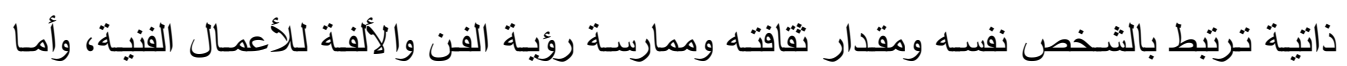

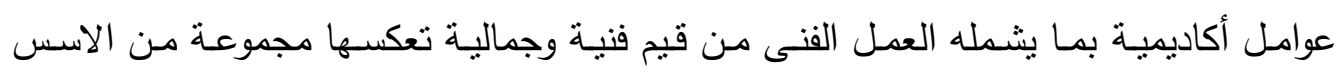

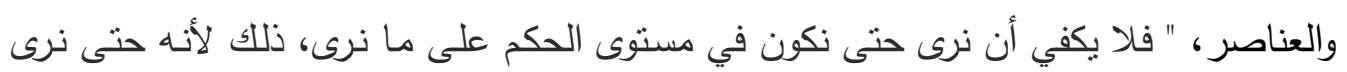
جيدا، يجب أن نعرف إلى ماذا ننظر وكيف ننظر في ما نرى " (خليل قويعه، 9 1 ـr، م). 


\section{سمات ومراحل التقبل البصري الفني:}

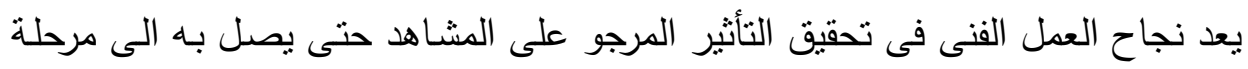

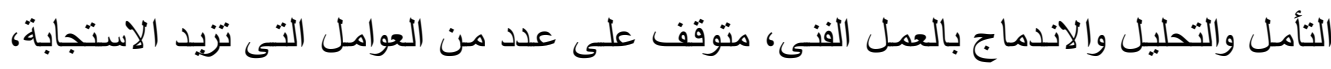

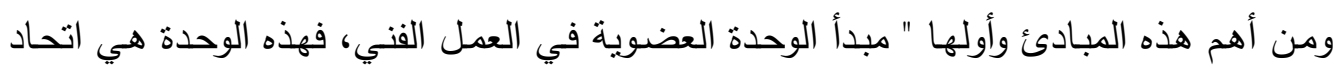

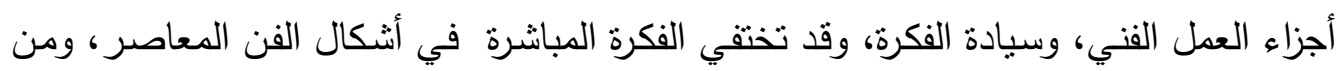
المبادئ الأخرى مبدأ التتوع، فقد يكون للموضوع الواحد أصداء وتكرارات وتتوعات، وكذللك مبدأ

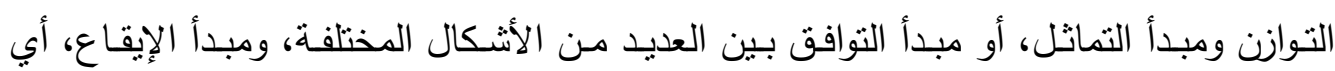

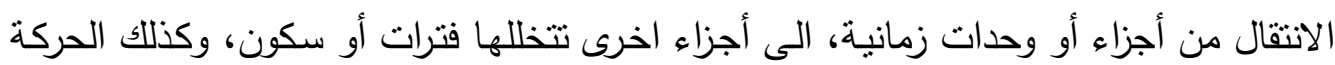

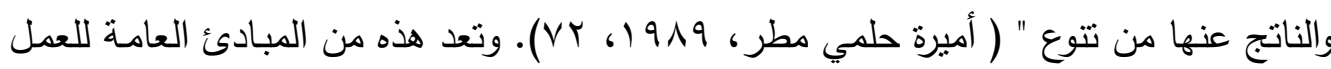

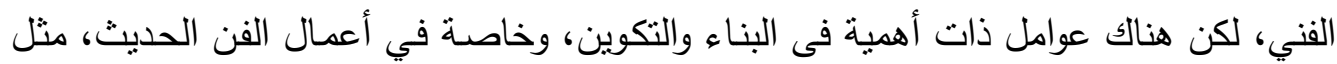

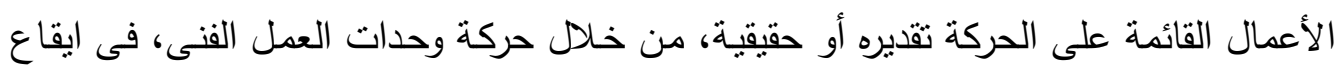

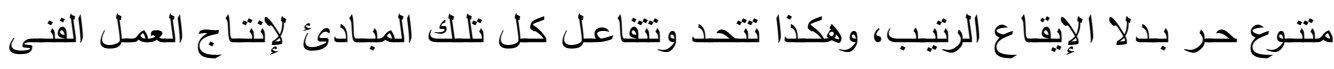
بصورته النهائية، الذي ينفعل بـه المنلقى والمتذوق للفن، ويكون لـه استجابة للمنظومة الجمالية

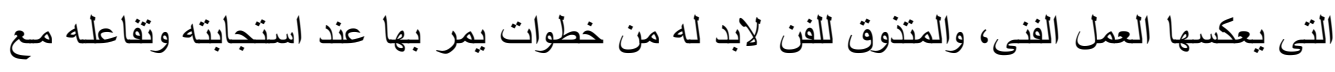

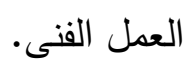

ع - خطوات الاستجابة الجمالية للعمل القنى •

يرى ريمون بايير (Raymond Bayer) أن الاستجابة الجمالية للعمل الفنى تتم وفق عدة

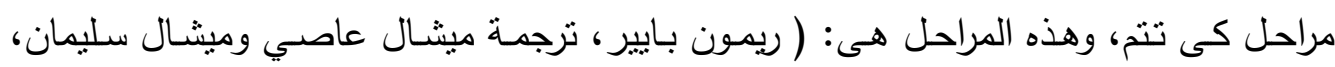

- - التوقف: بعد حدوث عملية الأدراك البصرى للعمل الفنى، تليه حدوث حالة من شد الانتباه

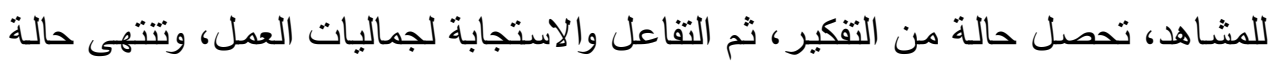

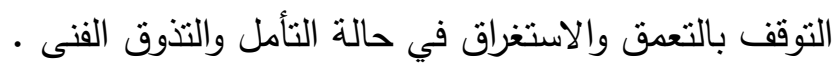
- - العزلة أو الوحدة: وهي الخطوة الثانية في عملية التذوق حيث يصبح للعمل الفني، قدرة على الاستحواذ الفكرى تجعل المنذوق والعمل الفنى في عالم جمالي قائم بذاته

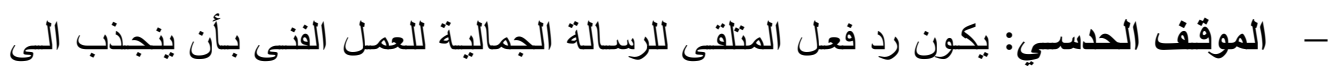

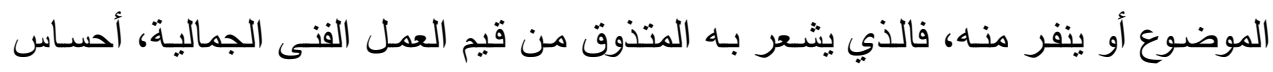
أقرب ما يكون الى الثعور الوصفي عند تأمله العالم المرئي الذي يعيش فئه فيه. 
- - الطابع العاطفي أو الوجداني : بعد أن فعل الحدس فعله في عملية التذوق الجمالي، يرتبط الموقف الجمالي باستجابة شخصية وجدانية، مبتعدة عن أي تصور عقلي

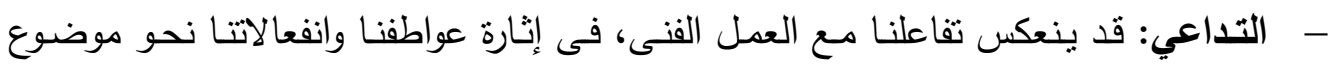

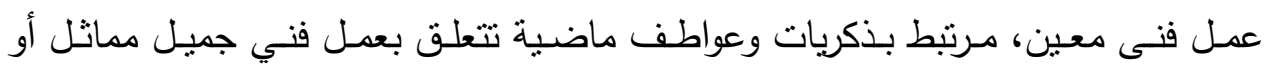
مشابه، فيقوي بذلك أحاسننا بتذوق العمل الفني القائم. - - التقمص الوجداني والتعـاطف الرمـزي: وهي المرحلة الأخيرة حيث يضـع المتذوق نفسـه موضع العمل الفني، بداخله أو جزء منه، حيث تحدث محاكاة تفاعلية ينتج عنها دمج بين المتلقى المنذوق والعمل الفني. يتبين مهـا سبق أن تأثز المشـاهد بالعهل الفنى ومـا يتبعـه مـن تفاعل معـه، تتحكم بـــ

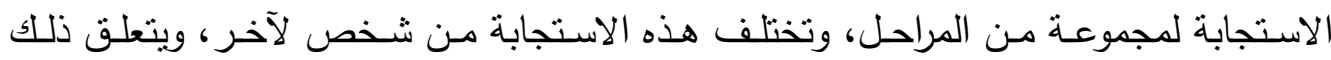
بالعديد من المعايير مثل مستوى الوعي والفهم، ودرجات التركيز والدقة والملاحظة، والمستوى الثقافي والوعي الجمالي، فضلا عن التحصيل الأكاديمي ونمط التقكير، مما ينعكس على درجة الإحساس والانفعال الجمالي بالعمل الفنى، فيصبح متلقى وفى النهاية متذوقا مقدرا للعمل الفنى بعد أن كان مشاهد له.

\section{ه - ديناميكية المتلقى وفاعلية الروئية .}

تم الاشارة سابقا الى أن الحركة منها أنواع، فمنها ما هو تقديرى غير حقيقى ومنها ما ماله هو فعلى، والحركة الفعلية منها أنواع تبع المسبب لها (القوى التى تنؤدى الى حدوث حركة

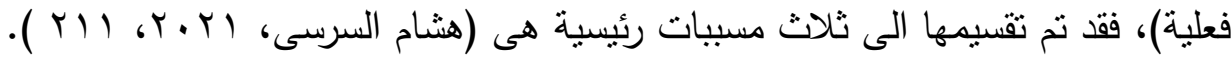
المسبب الأول : القوي الميكانيكية (الكهروميكانيكية والكهرومغناطيسية) .

$$
\begin{aligned}
& \text { المسبب الثانى (القوى الطبيعية) . } \\
& \text { المسبب الثالث (الحركة من خلال المشاهد) . }
\end{aligned}
$$

وتعد الحركة من خلال المشاهد من أكثر الأنواع التى ينتج عنها تعدد فى الرؤى الفنية

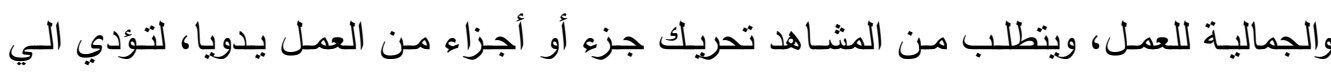

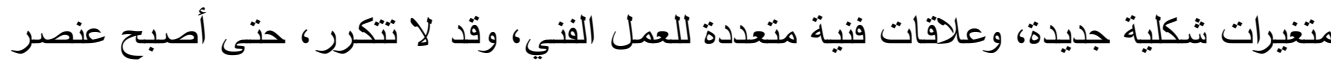
التقاعل من قبل المشاهد واحدا من أكثر الوسائل فاعلية ليزج به ليصبح جزء من العمل الفنى، وعى 
نتيجـة تحريكه لجزء أو اجزاء عدة مـن العمل الفنى ـ وقد يتسبب المشـاهد فى نوع أخر من

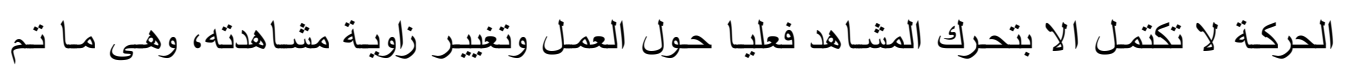

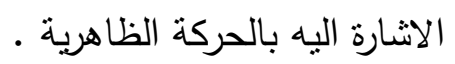

צ- الحركة الظاهرية للمتلقى وتعدد زوايا الروئية .

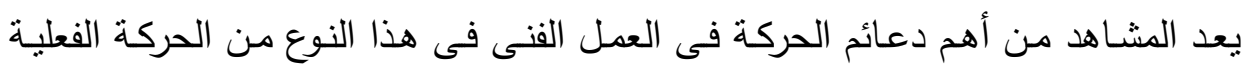
فيصبح هـو القوي المحركة للعمل الفنـي دون مساسـه، كأحد أجزاءه ، فيشـعر المشـاهد بأنسه مشارك في الأعمال عن طريق انتقال أثز الحركة من الثكل الي نفسه وعقله ، من خلال حركة دون العين المشاهدة للعمل، كما تم الاشـارة اليه، ولا تكتمل الرؤية الكلية للعمل وحركته بدونه، " فلم يعد دور المتلقى ينحصر فى مجرد الاستغراق فى تأمل ما أنجزه الفنان بعبقريته، وبفضل خياله الحر، وإنمـا العمل الفنى المعاصر يفترض إلغاء الحدود الفاصلة بين عناصر الثالوث الفنى (الفنان - العمل الفنى - الجمهور ) أو المشـاهد، وبخاصـة إن المتلقى قد مُنح دورا في تتميـة العمل الفنى، بل وفى تحويل مساره، رغم احتفاظ الفنان بامتلاكه لحق المبادرة ونتكيل التأثير،

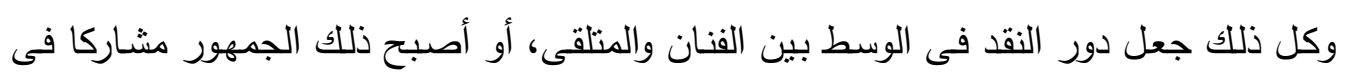

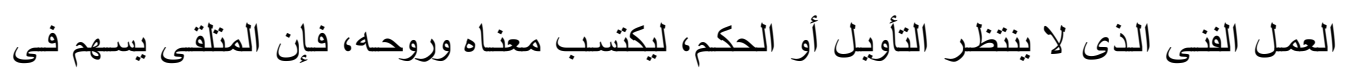

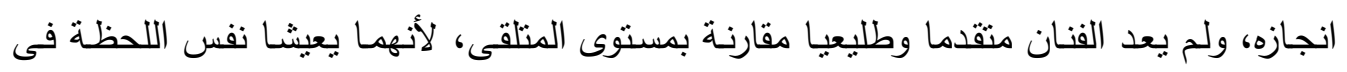

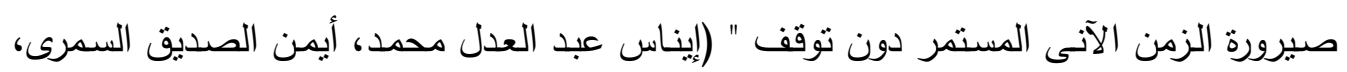

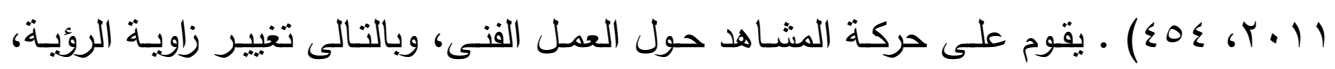
وتعدد الرؤى التصميمية للعمل، فيؤدى ذلك الى نوع من ثراء الروئية وظهور جماليات التصيم المجسم، ففي هذا الاتجاه يعد المشاهد هو القوي المحركة للعمل الفني باعتباره جزءاً لا يتجزأ

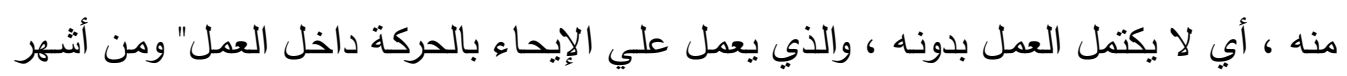

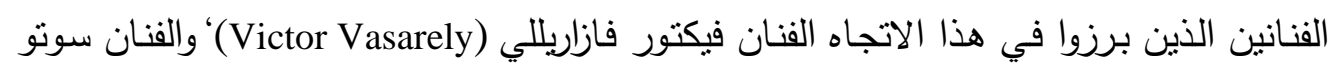

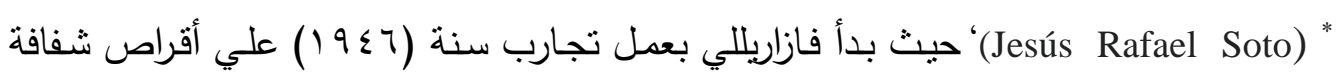

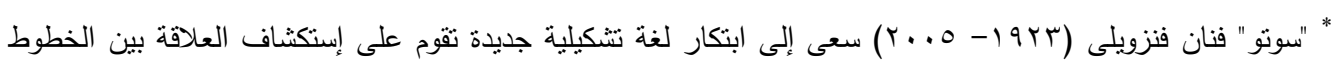

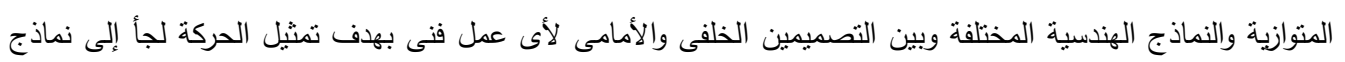


تنزلق الى فجوات ، فاعنبر رائدا لحركة (المرئيات التشكيلية) وقدم أعمالا أخري للفن الحركي سنة (1901)، حيث قدم أعمالا مكونة من عدة شاشات شفافة منظمة في أبعاد كانت تعرض للقوي الحركية الكامنة للخامات الثفافة المضاف اليها أسطح مرسومة أو ملونـة وهذه الأعمال

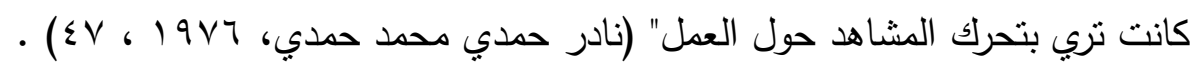

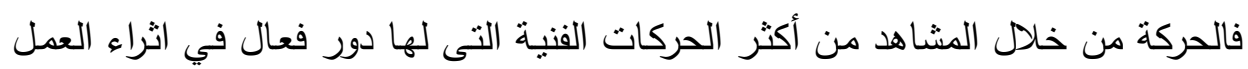

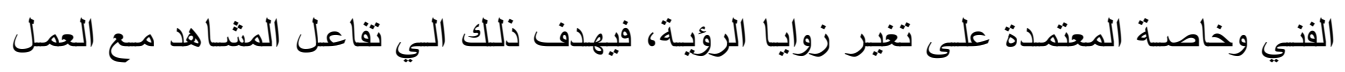
الفني، فهو يقوم بإقامة حوار مع الالوان والثفافيات والظلال، وفق شروط وقواعد معينة يحددها

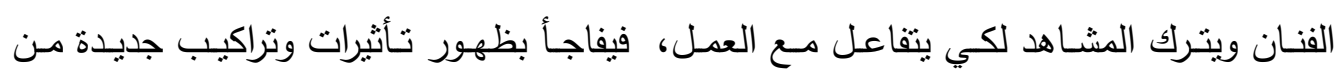
الاثكال والالوان ، فنجد ان هذا النوع من الحركة يترك تأثيرات نفسية وعضوية علي المشاهد، فتجذبه وتدفعه للتعامل مـع العمل الفني، والتعرف علي امكانياته ، وهذا النوع من العمل يجعل اشتراك المشاهد نوعاً من انواع الحركة الفعلية، والتي تتوقف حسب طبيعة العمل ودوره اثتاء

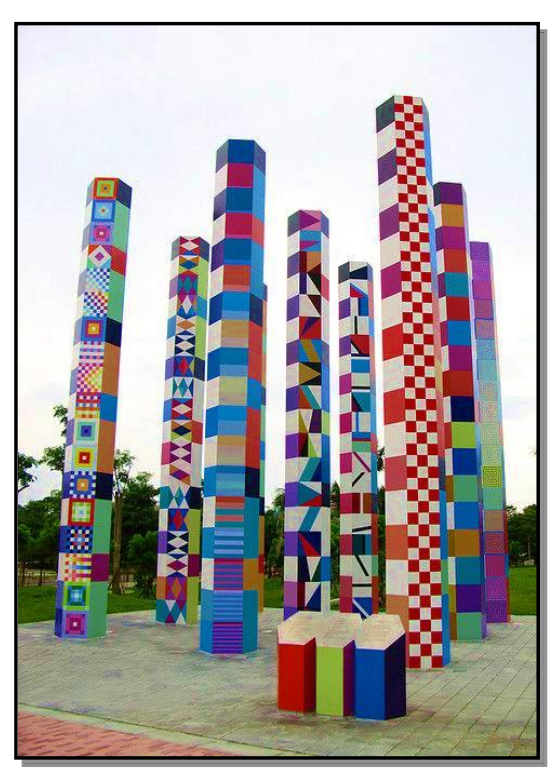

شكل رقم (r) عمل للفنان (YAACOV AGAM)

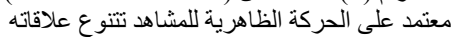

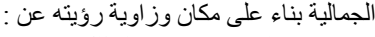
https://www.flickr.com/search/?text=YAAC OV\%20AGAM تشغيل العمل ـ فالمشاهد هنا هو محور حركة العمل الفني، فعين المشـاهد هي الكاميرا التي تسجل كل دقائق الأشياء التي تقع على شبكية العين، فحركة

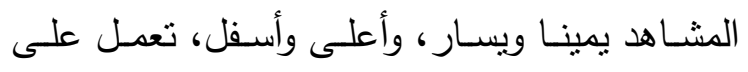
تغير زاويـة روئة للعمل الفني، مما ينتج العديد من

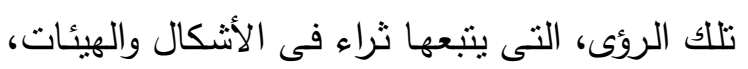
وتتـوع فـى العلاقـات اللونيـة، مدــا يثرى جماليـات العمل الفنى، كما فى شكل رقم (Y) . 


\section{V - الحركة الظاهرية (المنظور الحركى) فى التصميم.}

ويرتبط ذللك النوع من الحركة بالتصميمات المتعددة الاسطح أو المجسمئمة حقيقيـا، ولا تتحقق فى التصميمات ثنائية الابعاد ـ والحركة الظاهرية تتعلق بالتغيرات التى تحدث للإدراك

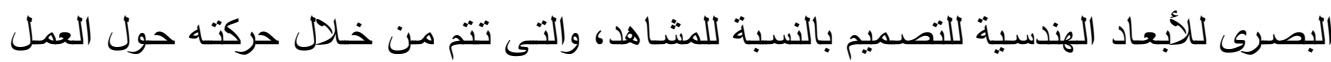

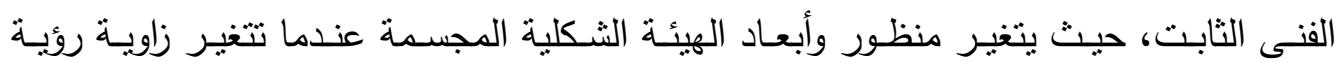
المشاهد للعمل الفنى، فعندما يتحرك المشاهد حول تصميم مجسم أو متعدد الأسطح فأنه يلاحظ الآتى: ( http://elbadryart.blogspot.com/2014/11/blog-post_28.html

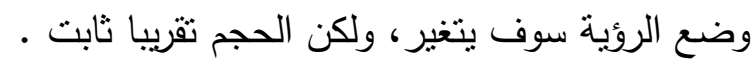

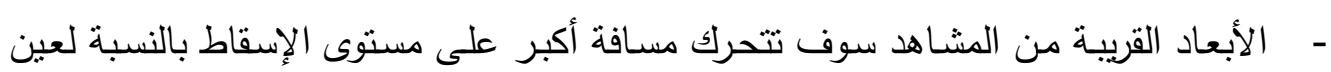

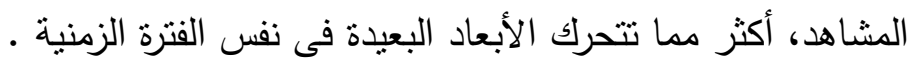

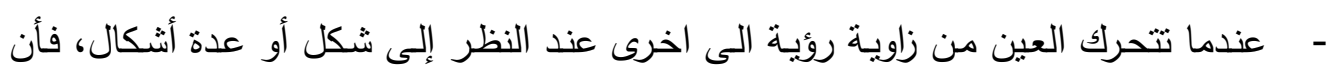

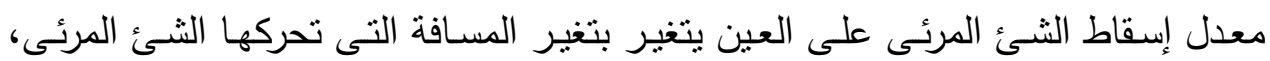

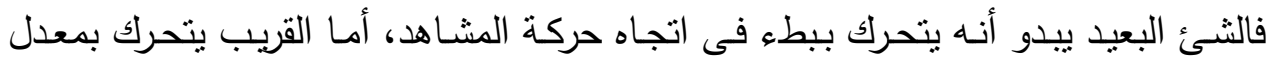

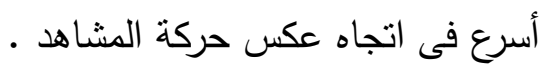

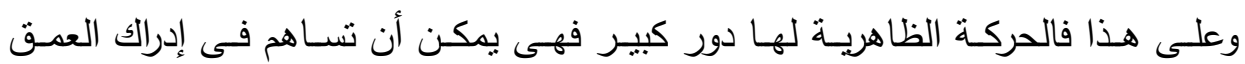
والمسافة بين الأجسام، فعندما تحدث حركة للمشاهد حول العمل الفنى . سوف تتحرك الأشياء المسطحة بسرعة أكبر مما تتحرك الأجزاء العميقة بالنسبة لرؤية المشاهد، ولذلك تعتبر الحركة

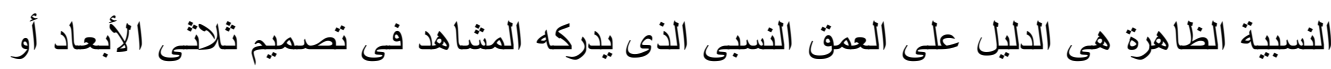

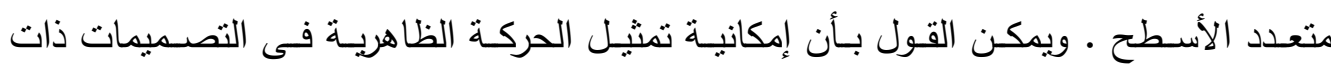
البعدين، من خلال الجمع بين أكثر من زاوية رؤية متتالية لعنصر أو مجموعة من العندية العناصر المجسمة ممثلة فى الفراغ الغير حقيقى. 


\section{ثُانياً: الإطار العملى:}

يعتمد الباحث فى هذا الإطلار على توضيح أبعاد الجانب التطبيقى للتجربـة التطبيقيـة وخطوات تتفيذها، وتوصيف وتتظير نتائجها من خلال اللوحة الزخرفية المجسمة حقيقيا، التى ينفذها الطلاب عينة البحث، كأحد مخرجات مجال التصميم، بعد عرض مـا توصل اليه من النتائج والمفاهيم ودراسـات تعرض لها البحث في الاطار النظرى السـابق، للاستقادة من تلك النتائج لطلاب الفرقة الثالثة بقسم التربيـة الفنيـة بكليـة التربية النوعيـة جامعـة المنوفيـة، ولقد تم التطبيـق العملى لتجربـة هـذا البحـث بهدف اثراء اللوحسة الزخرفيـة المجسـة تجسيم حقيقى، للوصول إلى أفاق إبداعية والكثف عن مكنونات الطاقات الحركية والتشكيلية واللونية والتأكيد عليها في صياغات وبناء وتلوين كل من اللوحة الزخرفية الأولى والثانية (كما سيتم توضيحه)، وذلك من خلال توظيف الحركة الظاهربة كمصدر للإثراء جماليات اللوحة الزخرفية المجسمة، ولقد تم النشاط التجربيى لهذه الدراسـة وفق مجموعة من الثوابت والمتغيرات، والتى تحدد حدود التجربة العملية، وسوف يتم عرض مجموعة من اللوحات الزخرفية، التي قام الطـلاب بتتفيذها، والقائمسة على اسـتثمار الحركـة الظاهربـة للمتلقى، ولتأكيد على ثراء الرؤيسة وتتوع الأشـكال ومفردات التصـيم، لتقديم مجموعـة مـن الصـياغات التصـيمية المتتوعـة، الغير تقليديـة للوحـة الزخرفية المجسمة حقيقيا، وفي ضوء ما سبق وتحقيق التجربة، تم ذلك اتباع بعض الخطوات من بداية العمل حتى نهايته مع الطلاب، وهى. 1- دراسة منهجية البحث الحالي في إطاره النظرى.

r- تتفيذ عدد تصميمين للوحة زخرفية مسطحة، للوصول الى اللوحة الزخرفية المجسمة حقيقيا

$$
\text { من اتباع وتتفيذ الأتى: }
$$

ب- التصميم الأول: تصميم وتتفيذ لوحة زخرفية مسطحة ذات حبكة تصميمية قائمة على عدد من حروف الخط العربى (حروف من أسم الطالب منفذ العمل) وممكن أن تتضمن كلمة واحدة فقط (أسم الطالب)، في مسـاحة . ب×× • سم على ورق الكانسون الابيض بثلاث ألـوان بـدرجاتهم بيـنهم علاقـة توافـق (مـع التأكيـد على عـدم اسـتخدام اللـون الأصـفر

من بينهم)

ع- التصميم الثانى : تتفيذ تصـيم من خـلال علاقات تلقائيسة للون عن طريق السكب لعدد ثلاثة ألوان منوافقة (بشرط يكون اللون الاصفر واحد منهم) في مساحة . ب.×. سم على ورق الكانسون الابيض لتحقق قيم لونية وخطية وملمسية وتتوع في المساحات . 
0- بعد الانتهاء من تتفيذ التصميم الأول والثانى. צ- - يقوم الطالب بتقسيم كل من التصميم الأول والثانى عرضيا إلى شرائح صغيرة كل منها

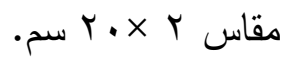

- - يتم ترقيم كل شريحة للتصميم الأول (اللوحة الزخرفية) من رقم (1) الى رقم (10 (10).

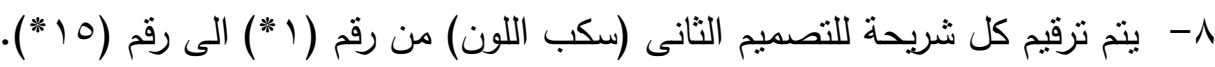
9- يتم قص شرائح كل تصميم على حدى بدقة .

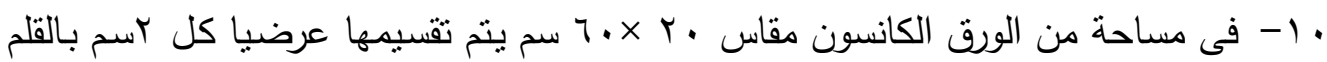
الرصاص إلى مسنطيلات صغيرة كل منها مقاس r × ×. سم عن ..

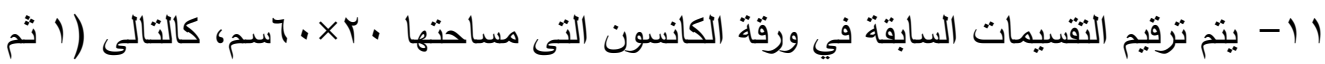

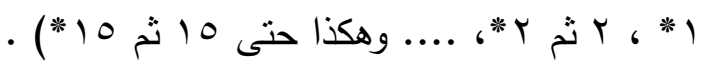

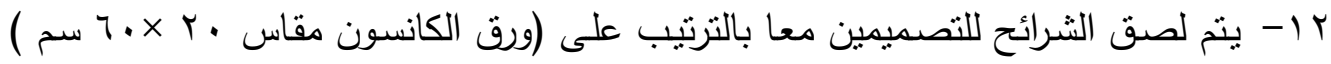

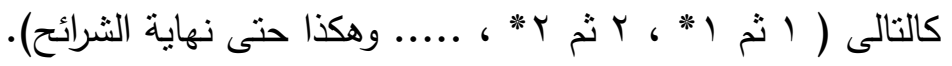

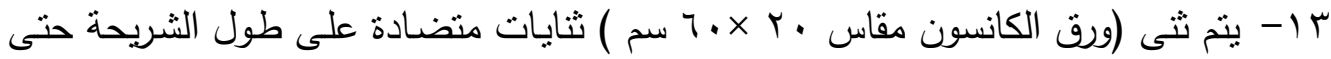

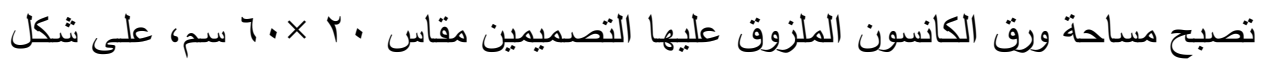
مروحة ورقية ذات ثثايات متضادة.

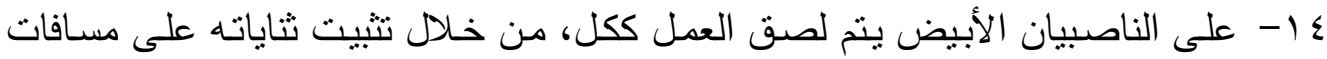
متساوية على بعد آسم في معظم اللوحات. 10- في بعض من اللوحات الزخرفية يتم لصق الثنايات بتتابع في مقاس المساحة فبدلا من

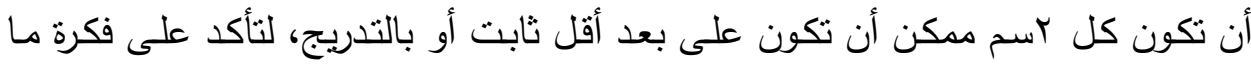
تضمنه اللوحة الزخرفية من إضاءة أو اعتام أو كثافة معينه لـأ.. إلخ.

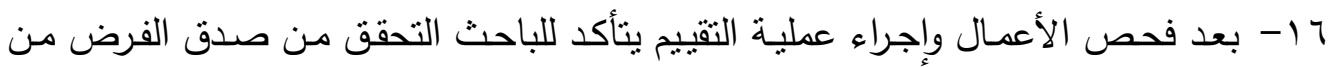

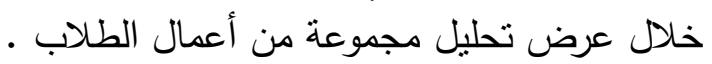

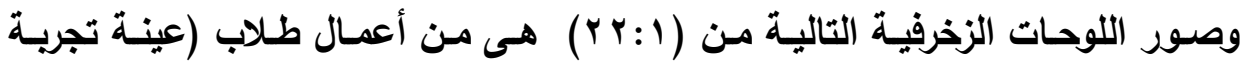

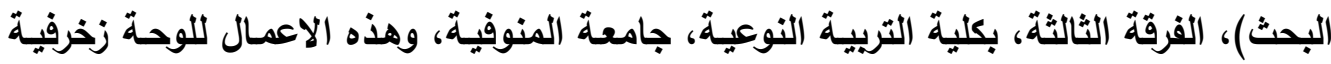
مجسمة حقيقا ذات رؤى تصميمية متعدة ومتنوعة، وسوف يقوم الباحث بالتحليل القنى العام

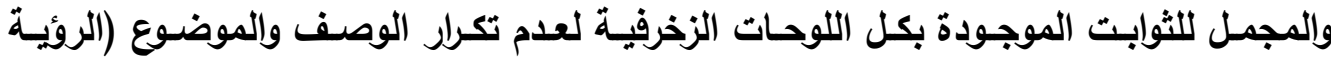

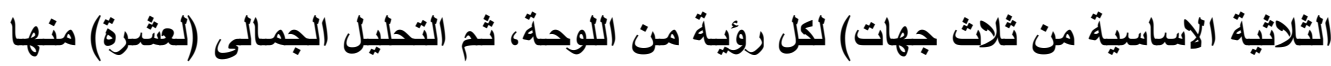

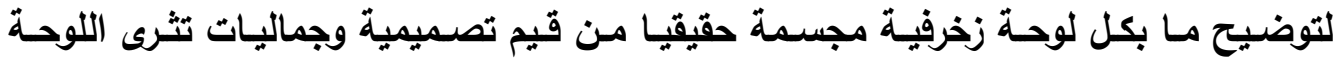
الزخرفية المجسمة في التصميم، والعرض لعدد من باقى اللوحات. 


\section{تحليل الأعمال القنبة:}

البيانات الخاصة باللوحات الزخرفية: المقاس : أعمال التجربة موحدة المقاس للوحة الزخرفية المجسمة حقيقيا فالعمل النهائى مقاس المقاس

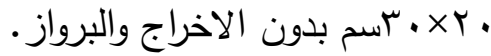

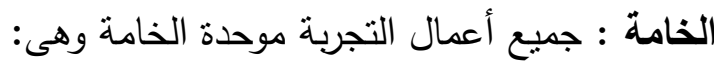
ألوان اكريلك وبوستر على ورق كانسون وناصبيان.

الوصف الخاص باللوحات الزخرفية:

العمل لوحـة زخرفيـة مجسمة تجسيم حقيقى ذات رؤى متعددة تتغير تبعـا لموقع وزاويـة رؤيـة المشاهد من العمل، فمع تحرك المشاهد وتغيير زوايا رؤيته للوحة الزخرفية، تتعدد أنثكال اللوحة دئه

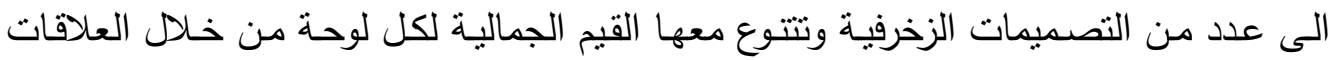

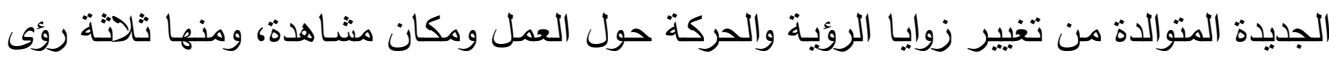

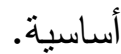

$$
\text { أولها: روئة للوحة زخرفية للحرف العربى من أحد الجوانب . }
$$

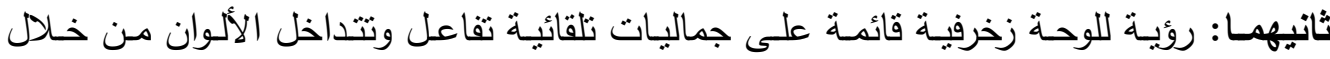

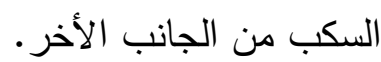
ثالثهما: رؤية للوحة زخرفية تشمل علاقة تصميمة منتوعة بين اللوحة الزخرفية الأولى والثانية فى عمل لونيا وتصميميا من الأمام. جماليات اللوحات الزخرفية: بجانب الرؤى الأساسية الثلاثة السابقة وما بهم من قيم وجماليات، فهناك رؤى بينية نظهر كلما

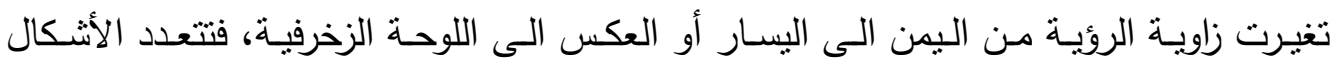

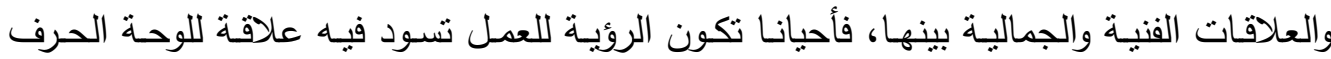

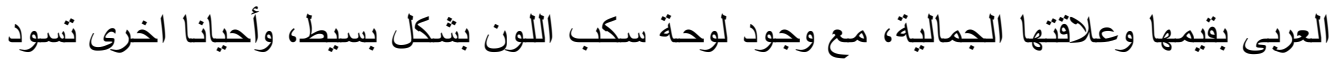

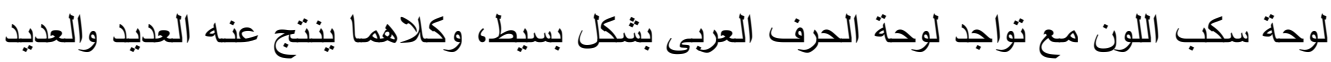
من الجماليات التصميمية من ايقاعات لونية وعلاقات نسبه وتتاسب بين المفردات وعلاقات لاتهات اتزان بين مفردات العمل والعمل الفنى ككل يتحقق به الوحدة من خلال اللون ودرجاته وعلاقاته وانسيابية المساحات اللونية، وكل هذا يؤدى الى زيادة فاعلية الروئية ونقل المشاهد بعد عمليات

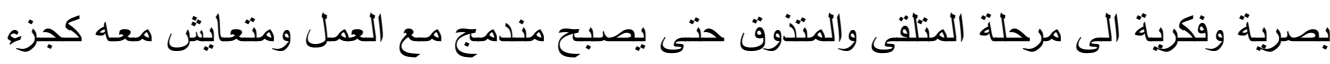
منه، وكل هذا يحقق فرضية البحث ويؤكد على أهدافه وأهميته. 
اللوحة الزخرفية المجسمة الأولى الئ

اسم الطالب : اسراء اسامه

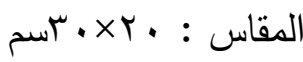

الخامة : ورق كانسون - ألوان اكريلك وبوستر

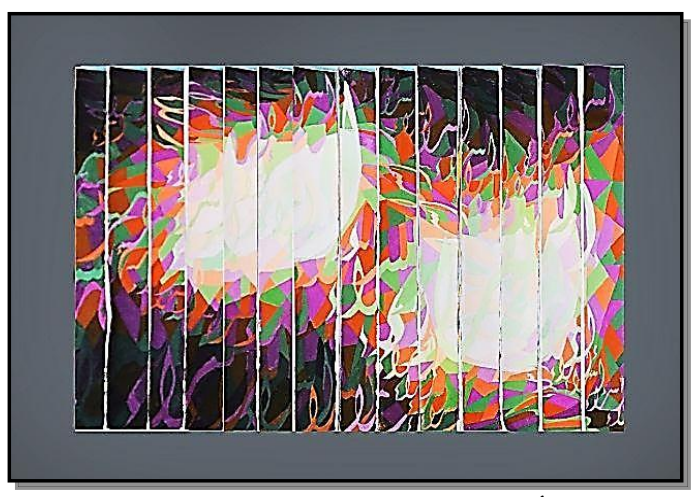

الرؤية الأولى (لوحة الحرف العربى) من الجانب الايمن حة
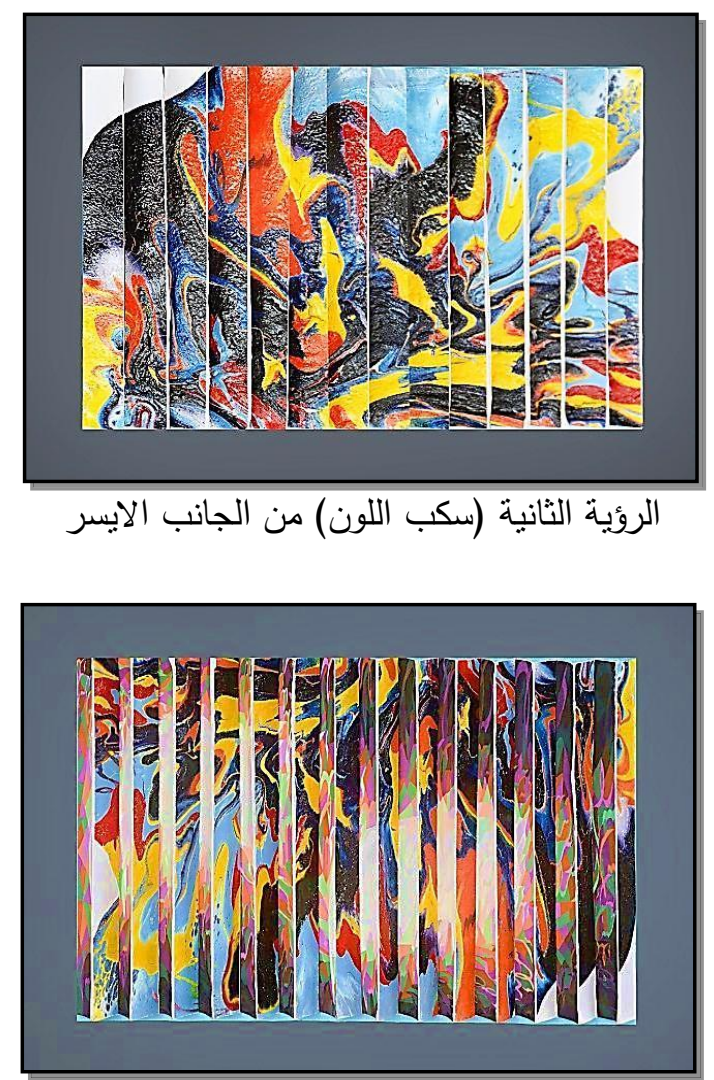

الرؤية الثالثة مزدوجة بين الحرف العربى والسكب
الرؤى الجمالية للوحة الزخرفية المجسمة حقيقيا : الروئة الأولى :

لوحة الحرف العربى تكرارات لحرف ال (س، أ، ر) في تراكبات وبها بؤرتين مضيئة احدهما اعلى من الاخرى وتغمق درجات اللون كلما اتجهنا الى الحواف في تتاغمات وتدرجات لونية وايقاعات للحروف . الروئية الثانية : لوحة لعلاقات لونيـة مـن خـلال سكب الوان الأزرق المسود والأصفر والأحمر واللبنى في تتاغمات وتداخلات لونية متتوعة المساحات والنسـب تـزداد في التفاصـيل والكثافـة في الاسـفل وتكبـر وتتنتـر كلمـا توجهنـا الـى الاعلى محققة الاتزان والوحدة ككل . الروئية الثالثة:

رؤيسة تجمـع بـين علاقـات الحـرف العربـى وسكب اللون في علاقة توافقية وتتاغم وتتوع بـين المسـاحات وايقاعهـا والملاحـظ علـى العمـلـ الثـراء الثــديد فـي حركـة الحـروف وحركات الـوان السـب واندماجها واختلاف زوايـا ميـلـ الثـرائح، فالعمـل لـه رؤيسـة ثربـة تتمتع بالعديد من القيم الجمالية واللونية لتية 
اللوحة الزخرفية المجسمة الثانتة

اسم الطالب : منار محمد المقاس : • • • • آسم الخامة : ورق كانسون - ألوان اكريلك وبوستر

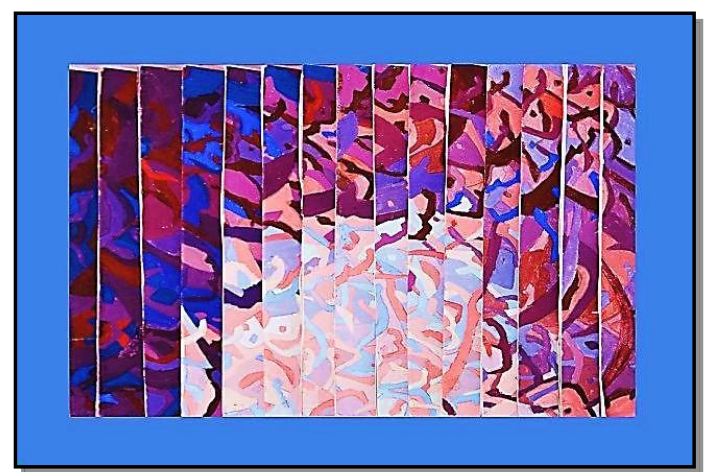

الرؤية الأولى (لوحة الحرف العربى) من الجانب الايمن

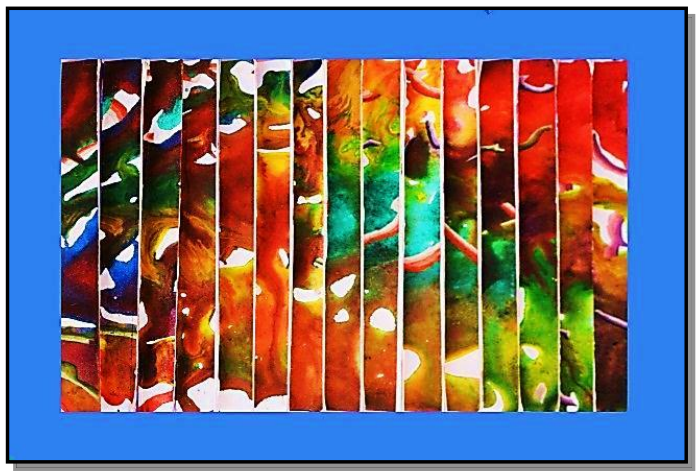

الروية الثانية (سكب اللون) من الجانب الايسر

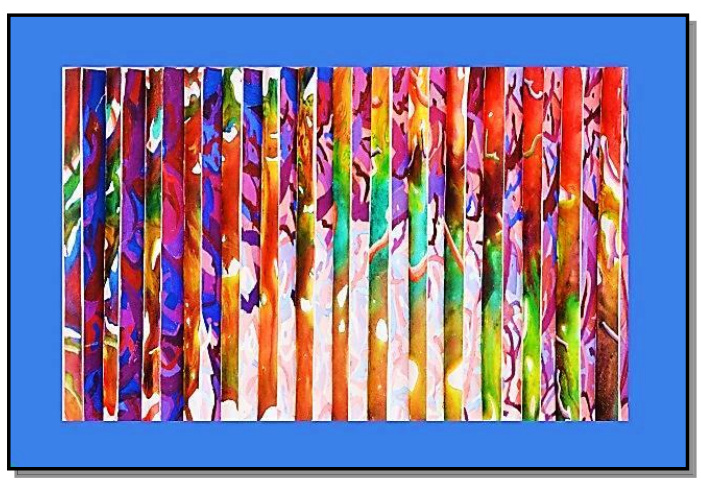

الروية الثالثة مزدوجة بين الحرف العربى والسكب
الروئى الجماليـة للوحة الزخرفيـة المجسمة

حقيقيا :

الروئة الأولى :

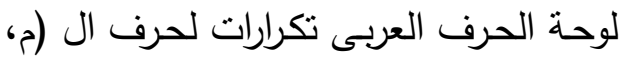
أ، ر ) في تراكبات وبها بؤرة مضيئة اعلى لكرات

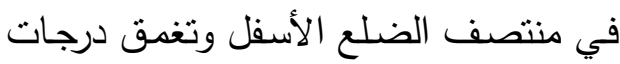
اللون كلما اتجهنا الى الحواف في تتاغمات وتدرجات لونية وايقاعات للحروف . الروئية الثانية : لوحـة لعلاقات لونية من خـلال سكب الوان

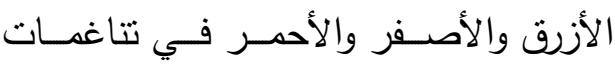
وتداخلات لونية منتوعة المساحات والنسب الاربـ

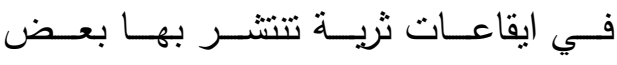

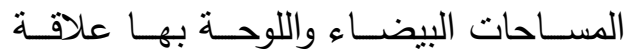
متتوعة المساحة بين الثكل والارضية . الروئية الثالثة : ملثوعه المباجه

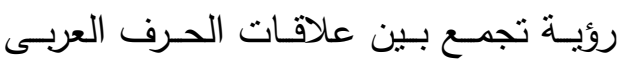
وسكب اللون في علاقة تتاغمية تتـوع بها

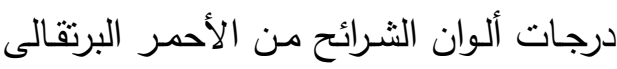

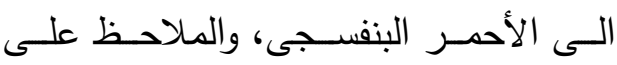

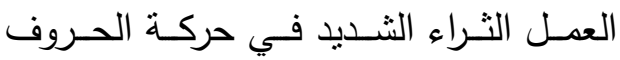
وحركات الوان السكب، فالعمل له رؤية ثرية تتمتع بالعديد من القيم الجمالية واللونية 
اللوحة الزخرفية المجسمة الثالثة

$$
\begin{aligned}
& \text { اسم الطالب : هدى يسرى } \\
& \text { المقاس : • • • • זسم }
\end{aligned}
$$

الخامة : ورق كانسون - ألوان اكريلك وبوستر

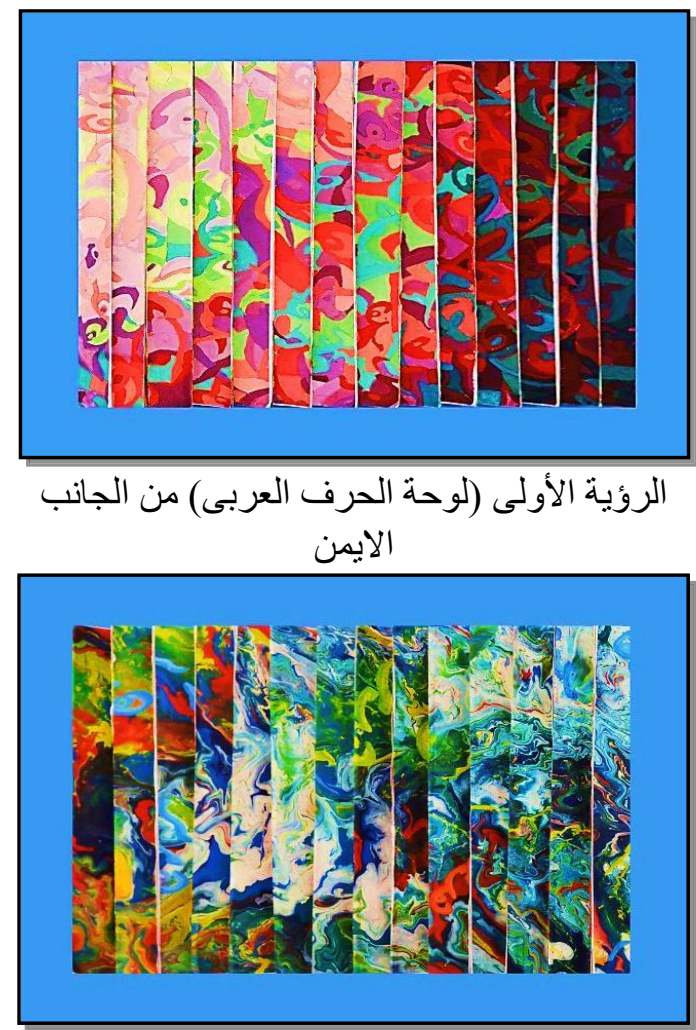

الروية الثانية (سكب اللون) من الجانب الايسر

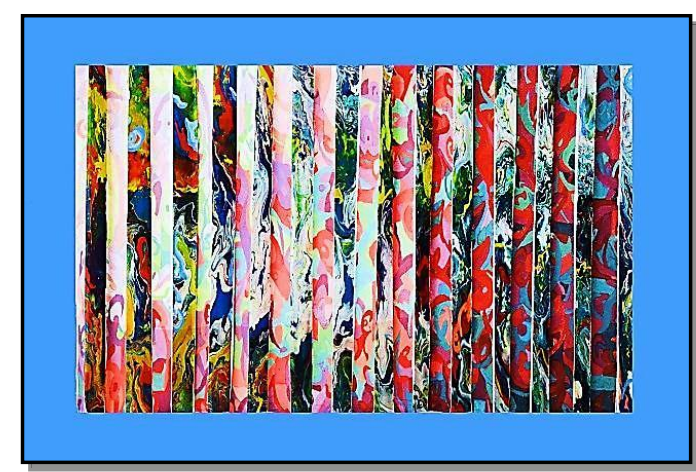

الروية الثالثة مزدوجة بين الحرف العربى والسكب
الرؤى الجمالية للوحة الزخرفية المجسمة حقيقيا : الروئية الأولى :

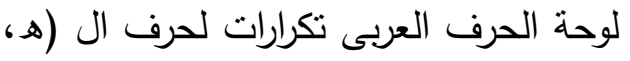

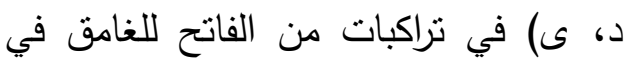
ركنين من التصميم الى الركن الأخر في تتاغمات وتدرجات لونية وايقاعات للحروف لون الخت

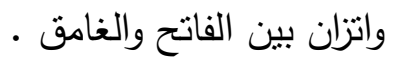
الروئية الثانية : لوحة لعلاقات لونية من خلال سكب الوان

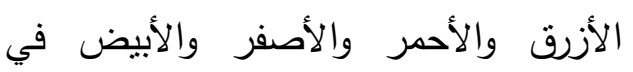
تتاغمات وتداخلات لونية خطية ومساحات ملمسية منتوعة بها بؤز تسود بها الألوان السابقة على اخرى، والتصميم يتميز بالتفاصيل الخطية والملامس . الروئية الثالثة : بالثان روية تجمع بين علاقات الحرف العربى وسكب اللون في علاقة توافقية وتتاغم وتتوع بين المساحات المضيئة والمعتمة نؤكدها زوايا روية الثرائح، والملاحظ على العمل الثراء الثديد، فالعمل له روئية ثرية نتمتع بالعديد من القيم الجمالية والعلاقات اللونية 
اللوحة الزخرفية المجسمة الرايعة اسم الطالب : عبد التواب على المقاس : • • • • الخامة : ورق كانسون - ألوان اكريلك وبوستر

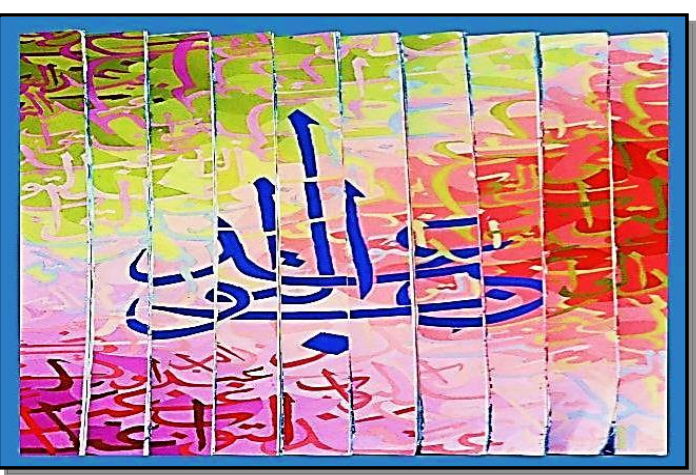

الرؤية الأولى (لوحة الحرف العربى) من الجانب

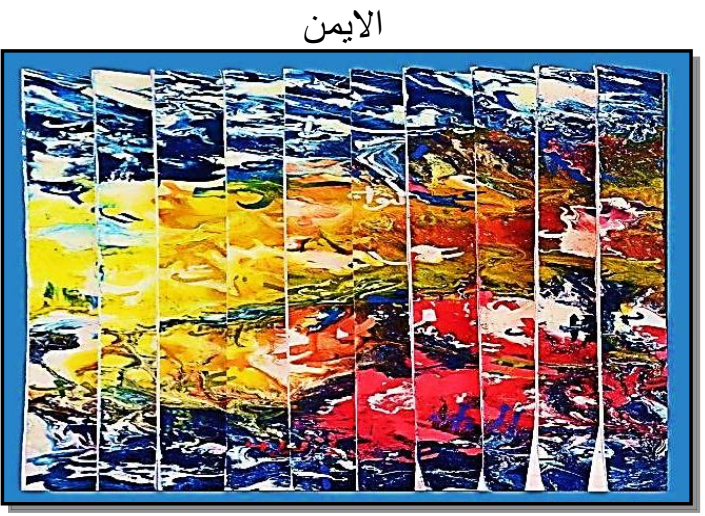

الرؤية الثانية (سكب اللون) من الجانب الايسر

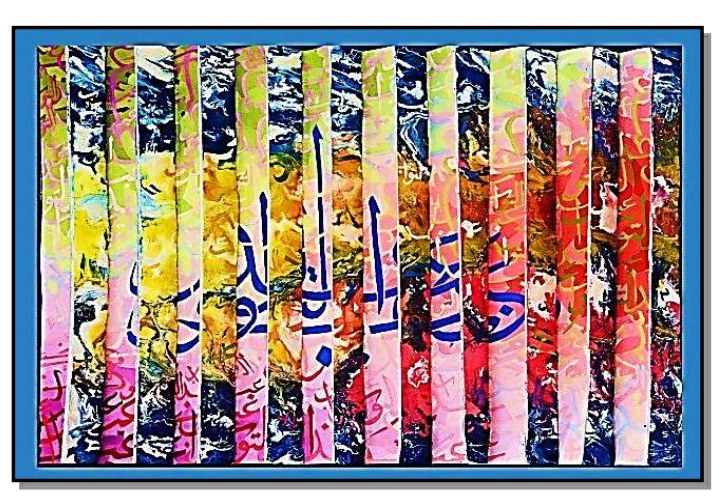

الروية الثالثة مزدوجة بين الحرف العربى والسكب
الرؤى الجمالية للوحة الزخرفية المجسمة حقيقيا : الروئية الأولىى :

لوحة الحرف العربى تكرارات لحرف ال (ع، لون، أ، ب، ت) في تراكبات وبها عدة بؤر لونية بدرجات لونية تتدمج بين الاساخن والبارد في لئ لئ

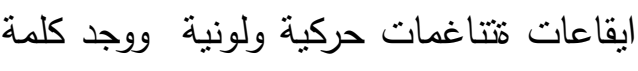
عبد التواب في المنتصف ويتحقق بالتصميم

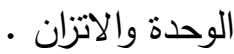

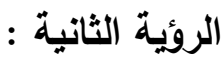
لوحة لعلاقات لونية من خلال سكب الوان الأزرق والأحمر والأصفر والأبيض في لهن تتاغمات وتداخلات لونية خطية ومساحات ملمسية متتوعة بها بؤز تسود بها لون السابقة على اخر، والتصميم يتميز بالتفاصيل الخطية والملامس و بحركة من جانب

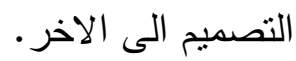
الروئية الثالثة : روية تجمع بين علاقات الحرف العربى وسكب اللون في علاقة مضيئة ومعتمة للشرائح تتناغم وتتتوع بين المساحات وايقاعها والملاحظ على العمل الثراء الثنديد في القيم

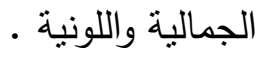


اللوحة الزخرفية المجسمة الخامسة

اسم الطالب : اهد فاروق المقاس : • • • • اسم الخامة : ورق كانسون - ألوان اكريلك وبوستر

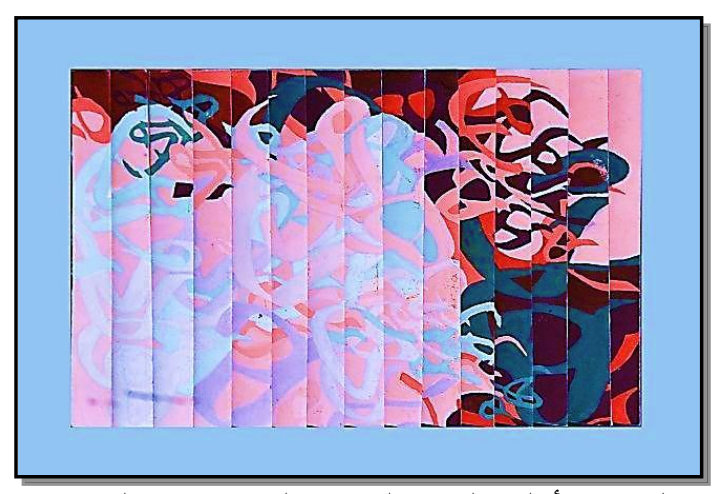

الرؤية الأولى (لوحة الحرف العربى) من الجانب الايمن

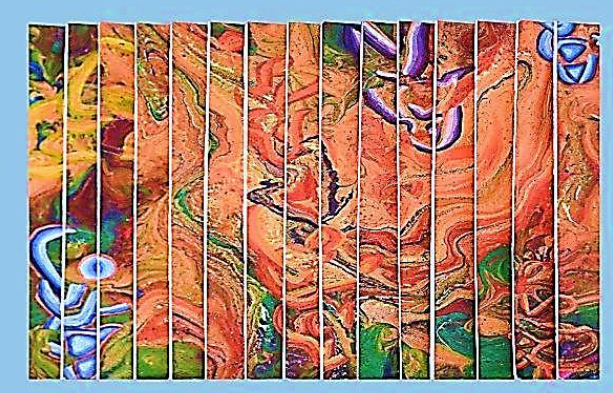

الروئية الثانية (سكب اللون) من الجانب الايسر

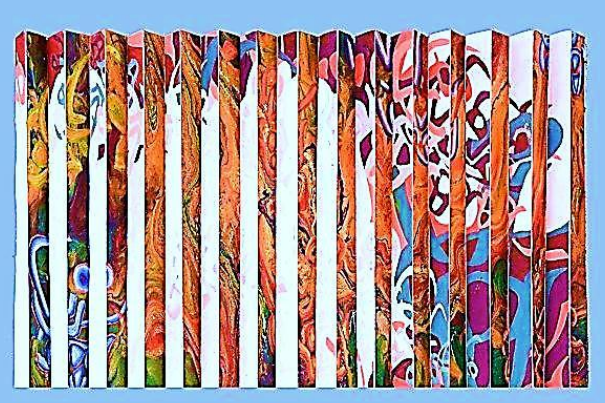

الروئة الثالثة مزدوجة بين الحرف العربى والسكب
الرؤى الجمالية للوحة الزخرفية المجسمة

حقيقيا : الروئية الأولى :

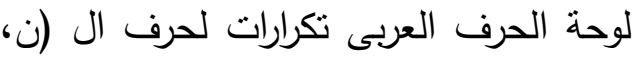
أ، هـ) في تراكبات من الفاتح للغامق في ركن لخرات لرن التصميم الى الركن الأخر في تناغمات وتدرجات لونية وايقاعات للحروف ونتاسب لترن

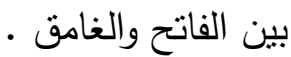
الروئية الثانية : لوحة لعلاقات لونية من خلال سكب الوان

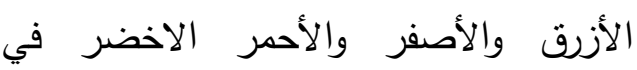
تتاغمات وتداخلات لونية منتوعة المساحات والنسب تزداد في التفاصيل والكثافة في حركه موجية تزيد وتقل وتنتشر في ايقاعات محققة

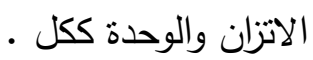
الروئة الثالثة : روية تجمع بين علاقات الحرف العربى وسكب اللون في علاقة توافقية وتتاغم وتتوع بين المساحات وايقاعها والملاحظ على العمل الثراء الثديد في حركة الحروف وحركات الوان السكب واندماجها واختلاف زوايا ميل الثرائح واضائتها، فالعمل له رؤية ثرية تتمتع بالعديد من القيم الجمالية واللونية . 
اللوحة الزخرفية المجسمة السادسة

اسم الطالب : هدى سليم

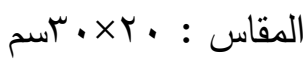
الخامة : ورق كانسون - ألوان اكريلك وبوستر

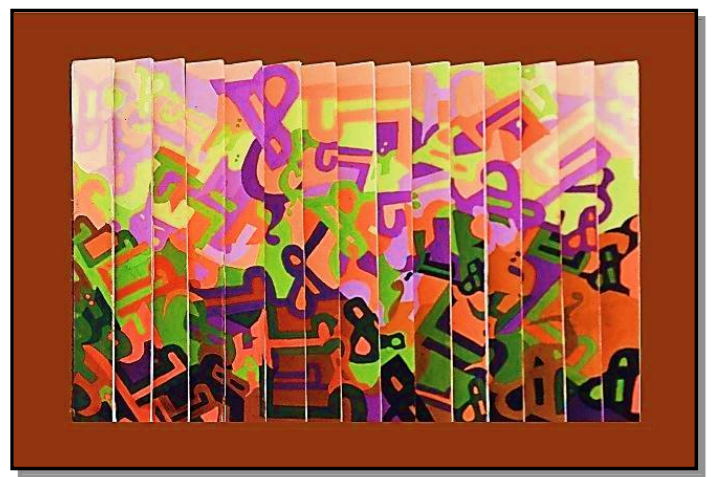

الرؤية الأولى (لوحة الحرف العربى) من الجانب

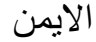

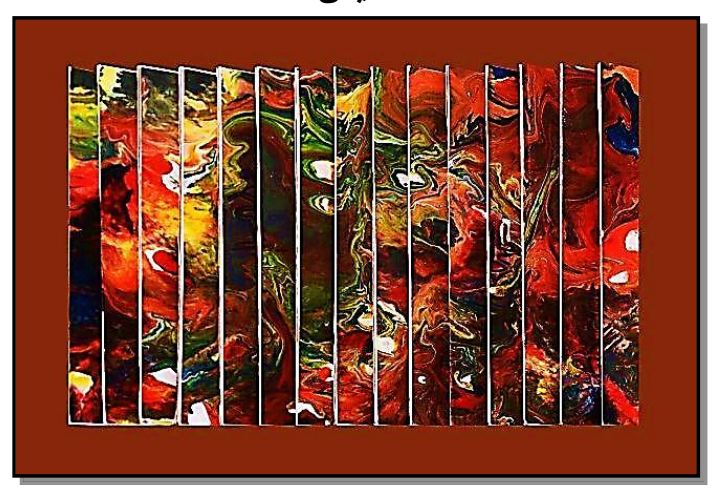

الروية الثانية (سكب اللون) من الجانب الايسر

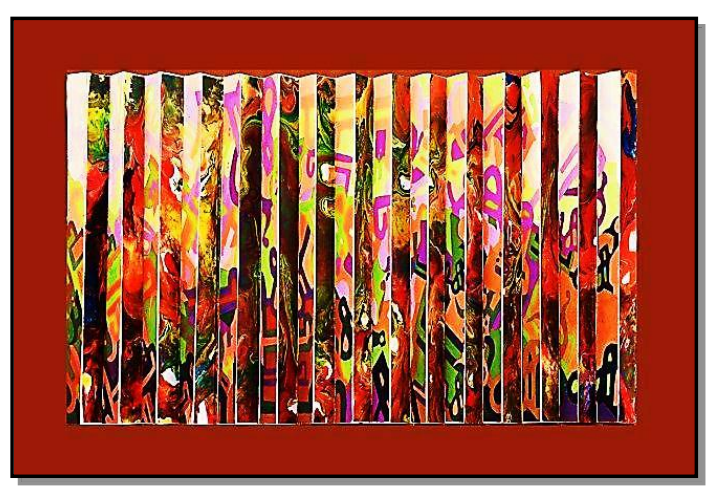

الرؤية الثالثة مزدوجة بين الحرف العربى والسكب
الرؤى الجمالية للوحة الزخرفية المجسمة حقيقيا : الروئة الأولى : الريا :

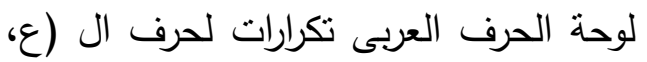
أ، ب، ت) في تراكبات وبها عدة بؤر لونية بدرجات لونية تتدمج بين الاساخن والبارد في لريات

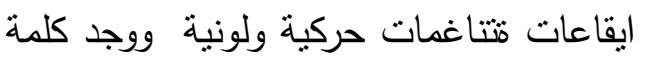
عبد النواب في المنتصف ويتحقق بالتصميم

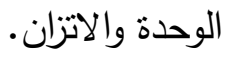
الروئية الثاتية: لوحة لعلاقات لونية من خلال سكب الوان الأزرق والأحمر والأصفر والأبيض في لمات لهن تتاغمات وتداخلات لونية خطية ومساحات ملمسية منتوعة بها بؤز تسود بها الألوان السابقة على اخرى، والتصميم بتميز بالتفاصيل الخطية والملامس والتصميم يتسم بحركة في الواتن السجب من جانب التصميم

$$
\text { الى الاخر }
$$

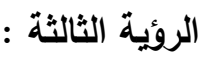

رؤية تجمع بين علاقات الحرف العربى وسكب اللون في علاقة مضيئة وعتمة لللشرائح توافقية وتتاغم وتتوع بين المساحات وايقاعها والملاحظ فئه

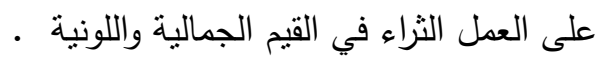


اللوحة الزخرفية المجسمة السابعة

اسم الطالب : اسراء محمد المقاس : • • • • اسم الخامة : ورق كانسون - ألوان اكريلك وبوستر

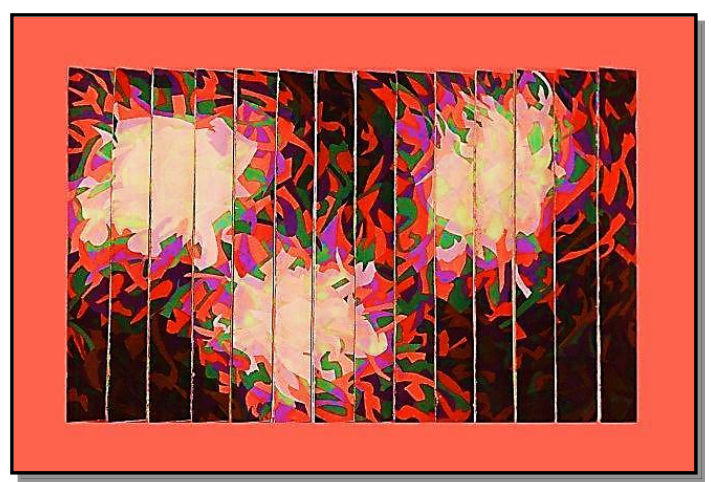

الرؤية الأولى (لوحة الحرف العربى) من الجانب الايمن

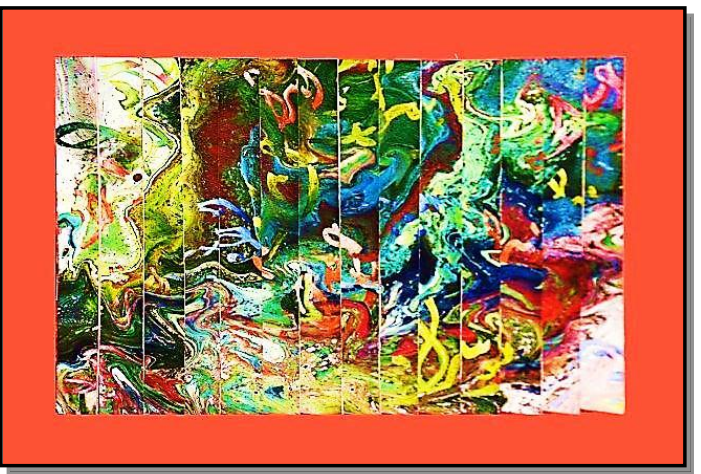

الروية الثانية (سكب اللون) من الجانب الايسر

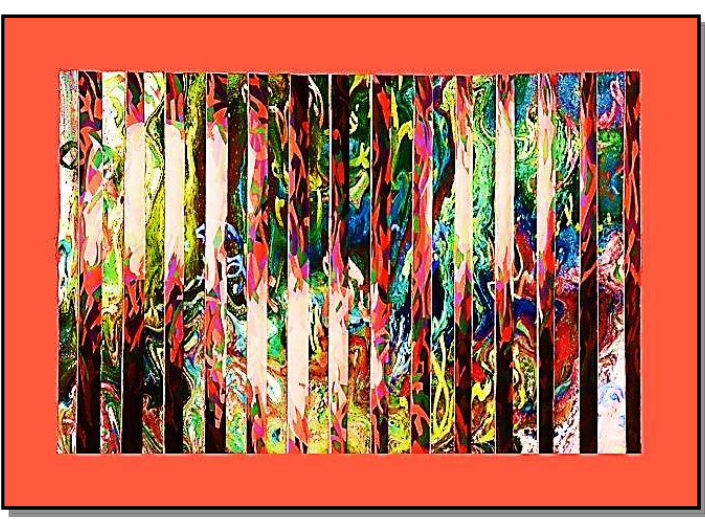

الروئة الثالثة مزدوجة بين الحرف العربى والسكب
الـرؤى الجماليـة للوحـة الزخرفيـة المجســة حقيقيا:

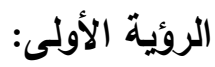

لوحة الحرف العربى تكرارات لحرف ال (س، الماوس، أ، ر ) في تراكبات وبها بؤرة مضيئة اعلى في لخرات منتصف الضلع الأسفل وتغمق درجات اللون كلمـا اتجهنـا الـى الحــواف فـي تتاغــــات وتدرجات لونية وايقاعات للحروف.

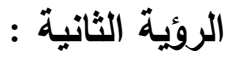
لوحـة لعلاقـات لونيـة مـن خـلاهل سـب الوان الوان

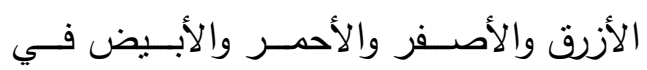
تتاغمات وتداخلات لونية منتوعة المساحات

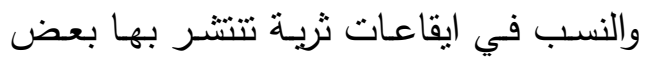

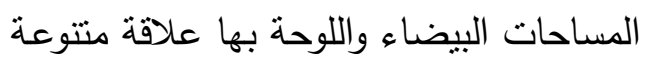
المساحة بين الثكل والارضية. الروئية الثالثة :

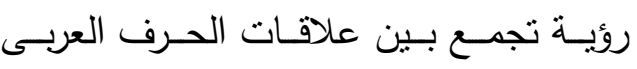
وسكب اللـون في علاقـة تتاغميـة تتـوع بها

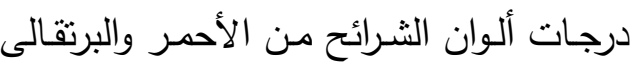

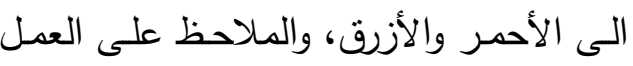
الثراء الثـديد في حركـة الحروف وحركـات الـوان السـكب، فالعمـل لـه رؤيـة ثريـة تثمتـع بالعديد من القيم الجمالية واللونية . 
اللوحة الزخرفية المجسمة الثامنة

$$
\text { السم الطالب : اسراء يسرى }
$$

الخامة: ورق كانسون - ألوان اكريلك وبوستر
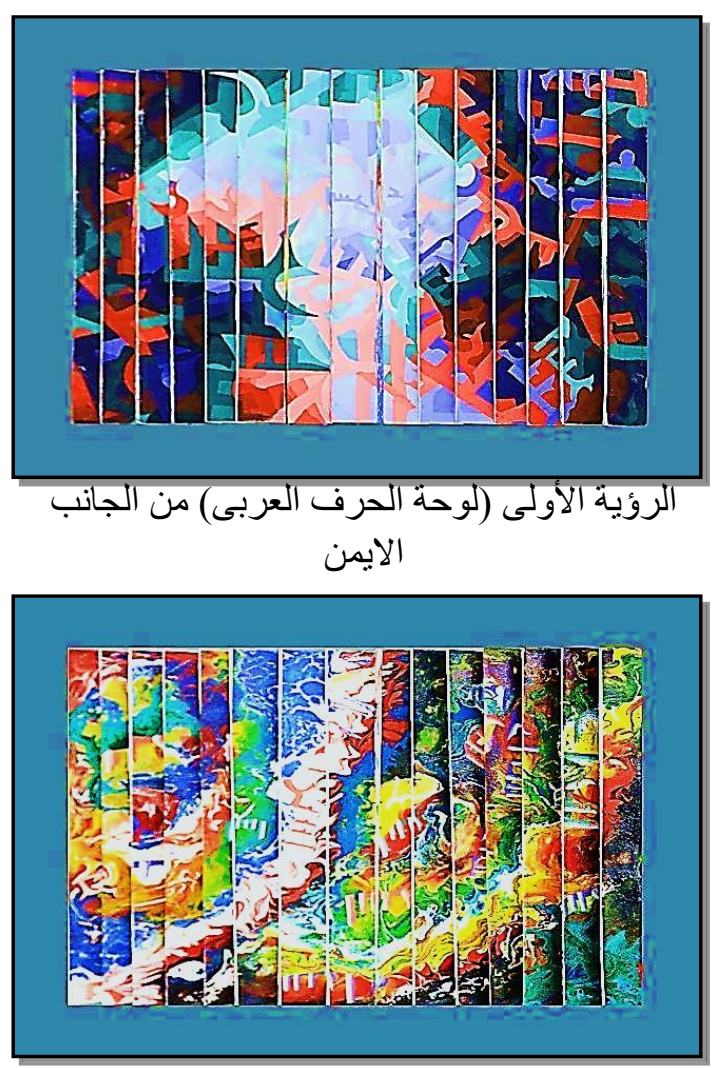

الرؤية الثانية (سكب اللون) من الجانب الايسر

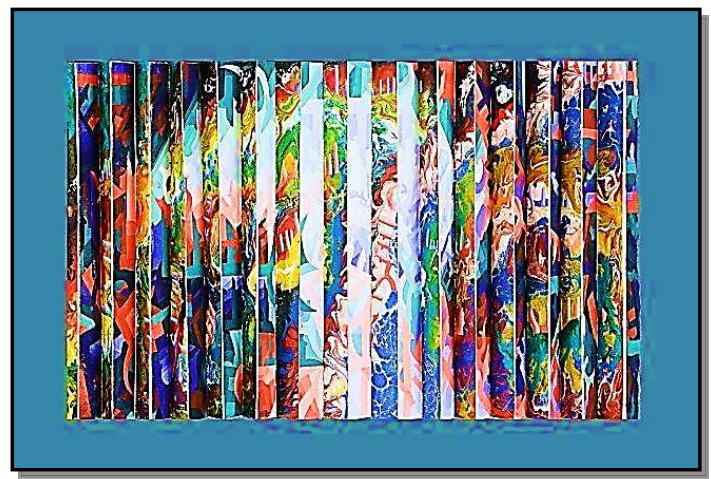

الروئة الثالثة مزدوجة بين الحرف العربى والسكب
الـرؤى الجماليـة للوحـة الزخرفيـة المجسـمة حقيقيا:

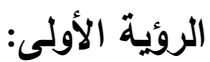

لوحة الحرف العربى تكرارات لحرف ال (س،

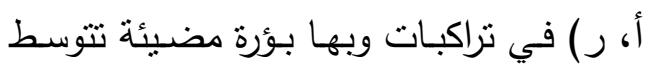

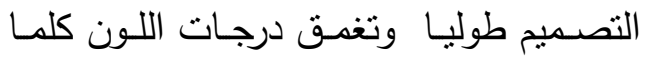
اتجهنـا الى الحـواف في تتاغمـات وتدرجات لونية وايقاعات للحروف واتزان كلى للوحة. الروئية الثانية: لوحـة لعلاقـات لونيـة مـن خـلال سكب الـوان

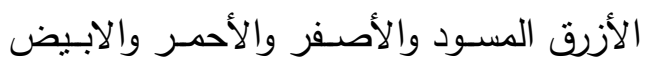

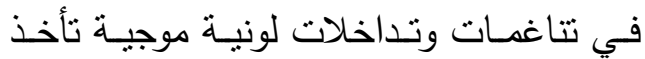
شكل اقواس متتوعة المساحات والنسب كثيرة في التفاصيل والملامس من خـلال التدخلات ولتهن والاقات اللونية.

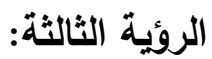

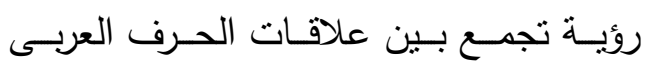
وسـكب اللـون في علاقـة تــاغم وتتوع بـين المساحات وايقاعها حركتها في شكل اقواس تؤكدها زوايـا ميلـ الثـرائح، فالعمل لـه رؤيـة ثرية تتمتع بالعديد من القيم الجمالية والتضـاد

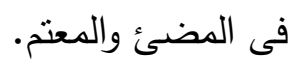


اللوحة الزخرفية المجسمة التاسعة

اسم الطالب : اسراء حمدى

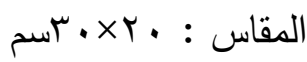
الخامة : ورق كانسون - ألوان اكريلك وبوستر

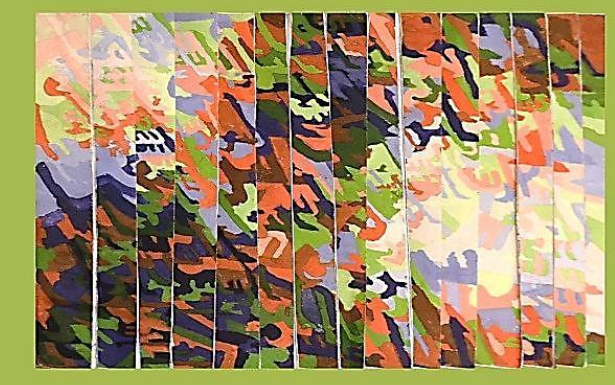

الرؤية الأولى (لوحة الحرف العربى) من الجانب الابمن الجرن

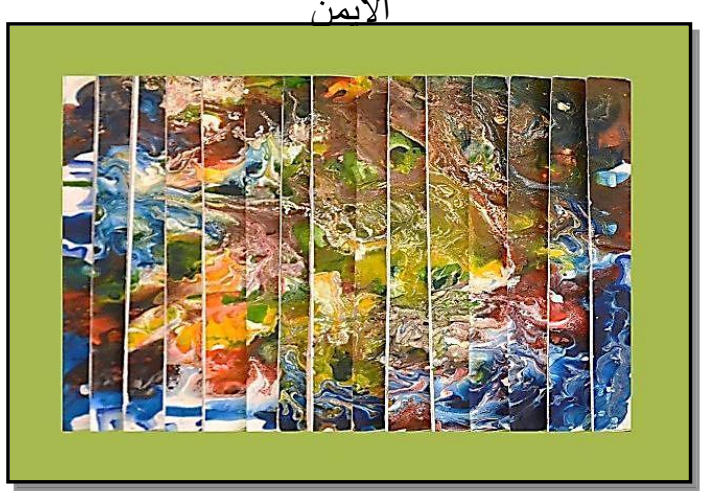

الروية الثانية (سكب اللون) من الجانب الايسر

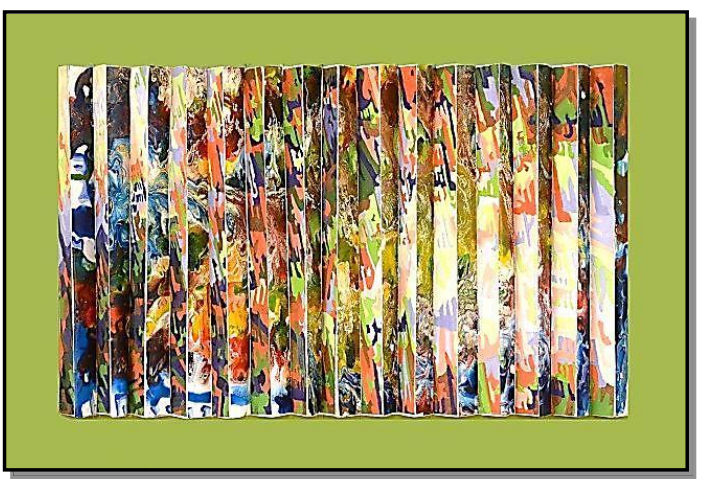

الروئة الثالثة مزدوجة بين الحرف العربى والسكب
الـرؤى الجماليـة للوحـة الزخرفيـة المجسـمة

حقيقيا : الروئة الأولى :

لوحة الحرف العربى تكرارات لحرف ال (ن، أ، هـ) في تراكبات من الفاتح للغامق في ركن التصــميم الـى الـركن الأخـر فـي تتاغمـات وتدرجات لونيـة وايقاعـات للحـروف وتتاسـب

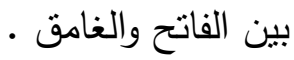
الروئية الثانية : لوحسة لعلاقات لونيـة مسن خـلال سكب الوان الأزرق والأصــفر والأحمـر الاخضــر فـي تتاغمات وتداخلات لونبـة متنوعـة المساحات والنسب نزداد في التفاصيل والكثافة في حركه موجية تزيد وتقل وتتنشر في ايقاعات محققة

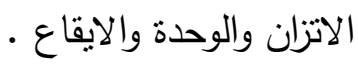
الروئية الثالثة : رؤيسة تجمـع بـين علاقـات الحـرف العربـى وسكب اللون في علاقة توافقية وتتاغم وتتوع بين المساحات وايقاعها والملاحظ على العمل الثـراء الثـديد في حركـة الحـروف وحركـات الوان السكب واندماجها واختلاف زوايـا مبـل الثــرائح وإضـاءتها، فالعمـل لـه رؤبـة تتمتحع بالثراء فى القيم الجمالية واللونية. 
اللوحة الزخرفية المجسمة العاشرة

اسم الطالب : هبه احمد المقاس : • • • • آسم الخامة : ورق كانسون - ألوان اكريلك وبوستر الرؤى الجمالية للوحة الزخرفية المجسمة

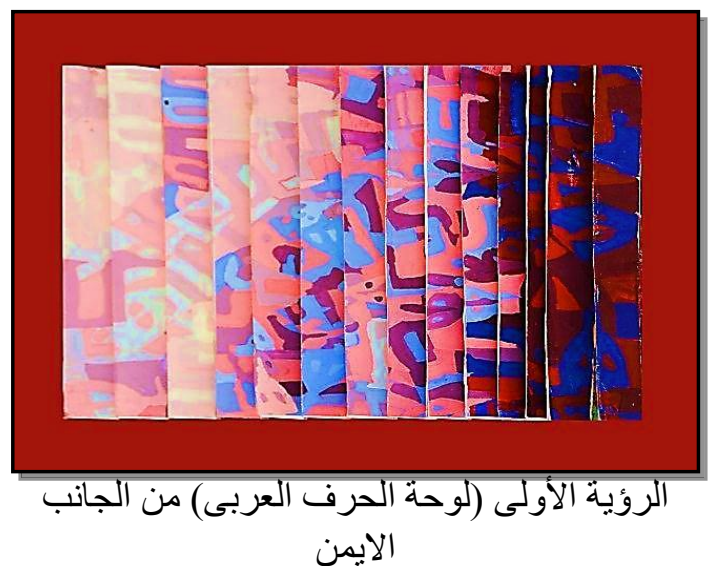

حقيقيا : الروئية الأولى :

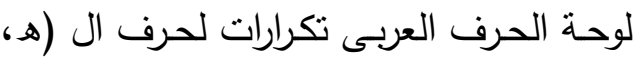
ب ) في تراكبات وبها اضاءة في احد جانبى لهرب

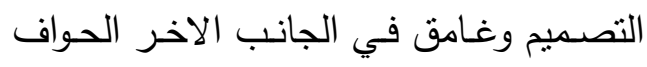

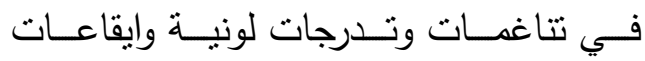
للحروف

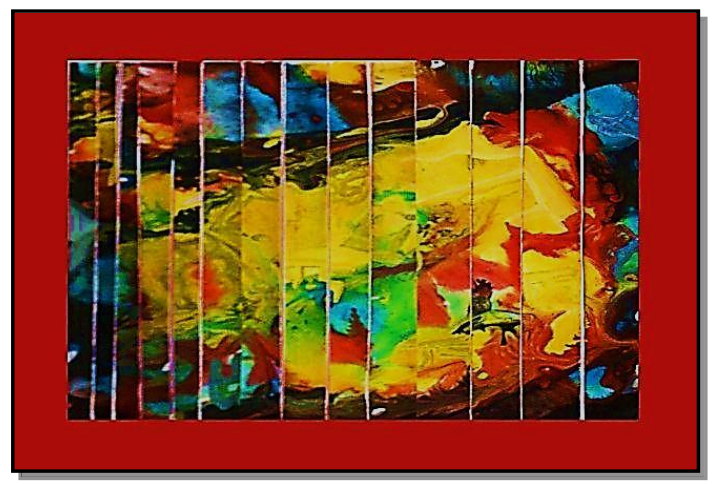

الروئية الثانية :

لوحـة لعلاقـات لونيـة مـن خـلال سكب الـوان

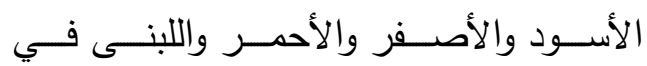
تتاغمـات وتداخلات لونيـة متتوعـة المسـاحات والنسب ويتميز العمل ببؤرة صفراء في وسط

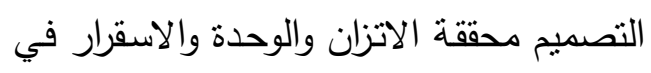

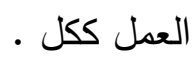
الروية الثانية (سكب اللون) من الجانب الايسر الروية الثالثة :

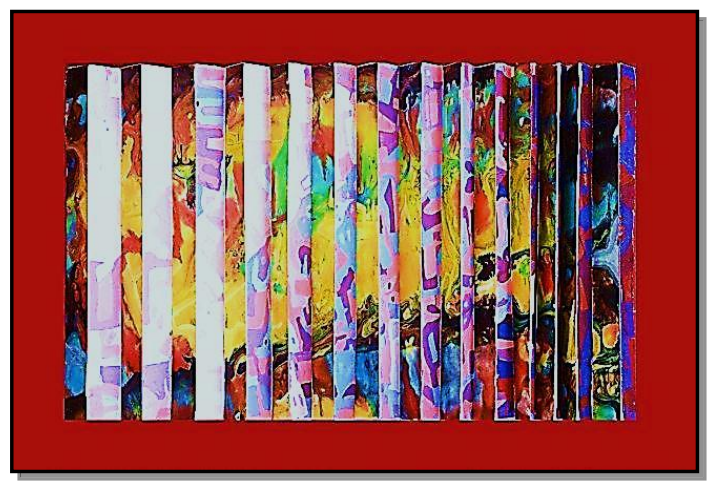

الروئة الثالثة مزدوجة بين الحرف العربى والسكب

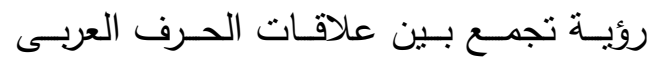
وسكب اللون في علاقة توافقية وتتاغم وتتوع

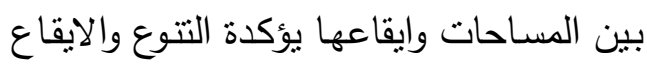

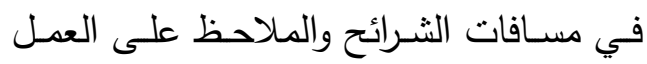
الثراء الثـديد في حركـة الحـروف وحركـات

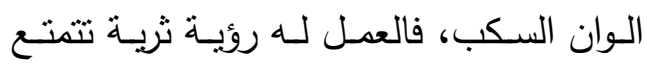
بالعديد من القيم الجمالية واللونية . 
اللوحة الزخرفية الثانـة عشر
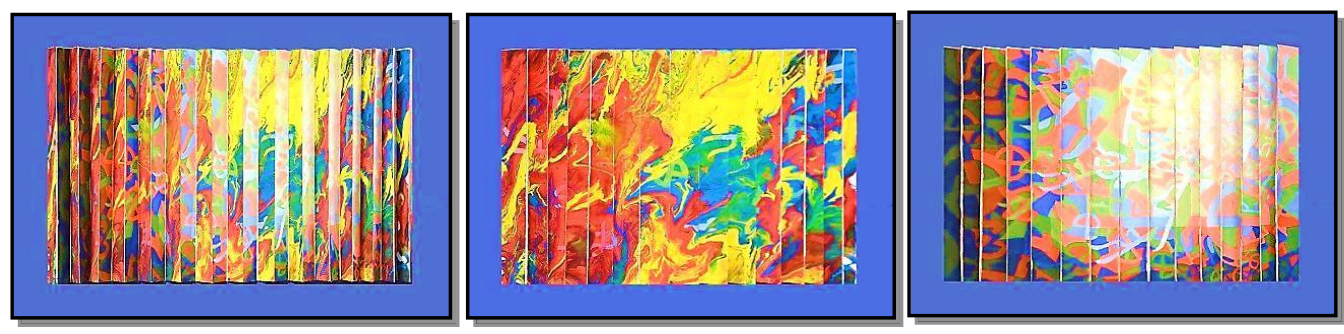

الرؤية الثالثة (مزدوجة) من المواجهة

الرؤية الثانية من الجانب اليسار

الرؤية الاولى من الجانب الايمن اسم الطالب : امنية مجدى الانب الائ

اللوحة الزخرفية المجسمة الحادية عشر

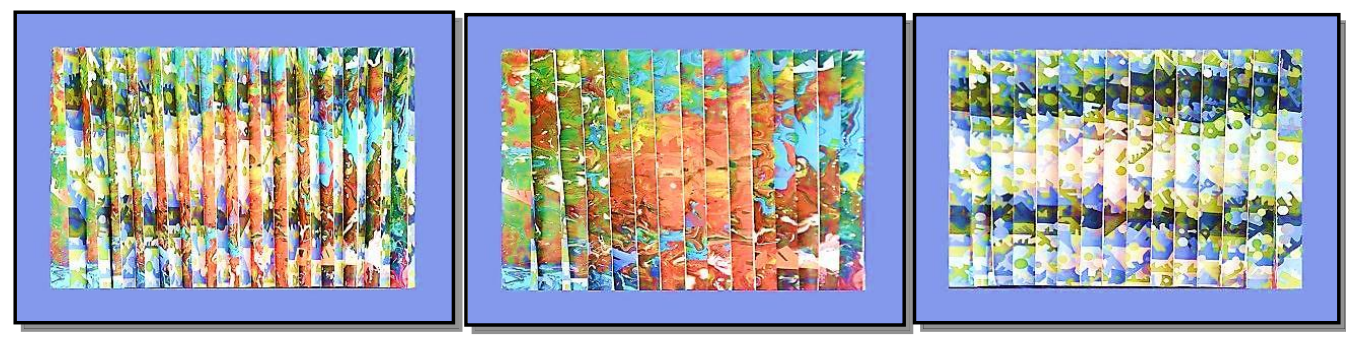

الروئة الثالثة (مزدوجة) من المواجهة

الرؤية الثانية من الجانب اليسار

الرؤية الاولى من الجانب الايمن

اسم الطالب : ابر اهيم على الجئ الاني

اللوحة الزخرفية المجسمة الثالثة عشر
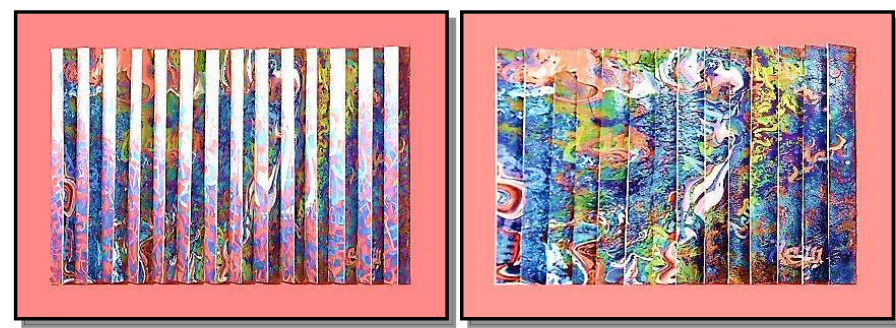

الرؤية الثالثة (مزدوجة) من المواجهة

$$
\text { الرؤية الثنانية من الجانب اليسار }
$$$$
\text { الرؤية الاولى من الجانب الايمن }
$$

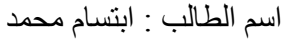

\section{اللوحة الزخرفية المجسمة الرابعة عشر}

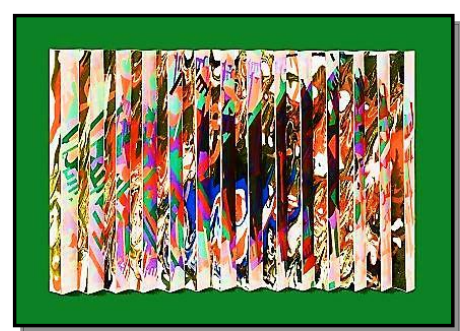

الرؤية الثالثة (مزدوجة) من المو اجهة

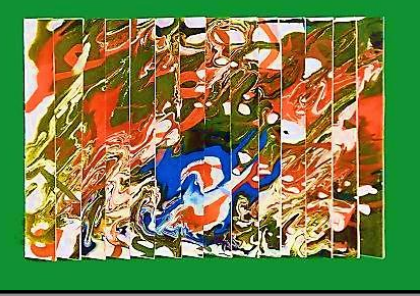

الرؤية الثانية من الجانب اليسار

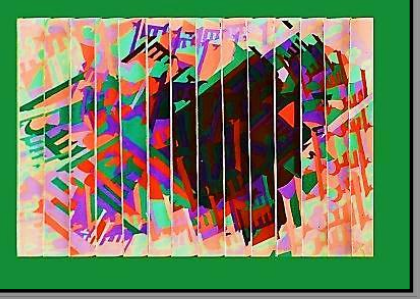

الرؤية الاولى من الجانب الايمن اسم الطالب : اسر اء بسيونى الجيان الإني 


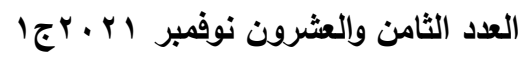

المجلة العلمية لكلية التربية النوعية

اللوحة الزخرفية المجسمة الخامسة عشر
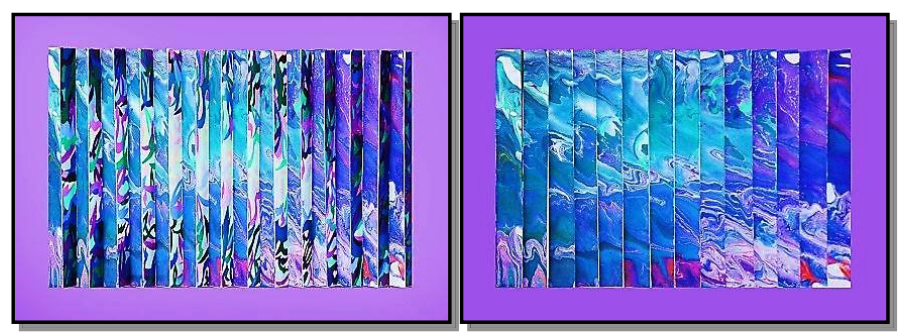

الرؤية الثانية من الجانب اليسار الرؤية الثالثة (مزدوجة) من المواجهة

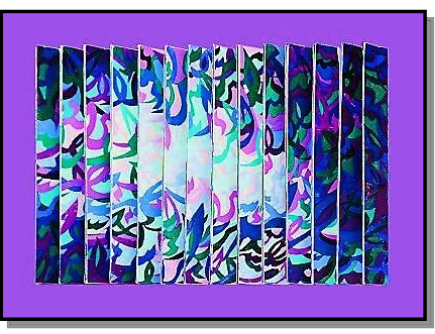

الرؤية الاولى من الجانب الايمن

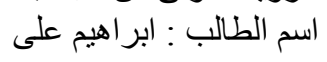

اللوحة الزخرفية المجسمة السادسة عشر

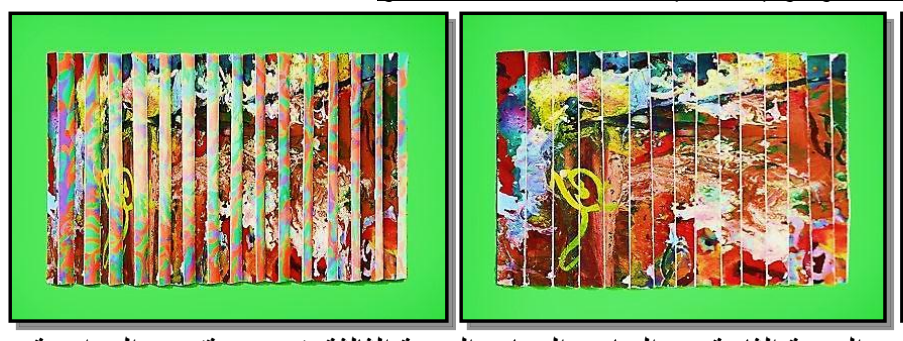

الرؤية الثانية من الجانب اليسار الرؤية الثالثة (مزدوجة) من المواجهة

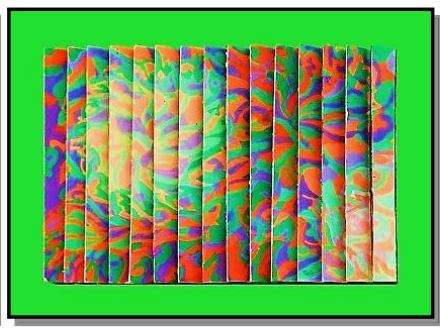

الرؤية الاولى من الجانب الايمن اسم الطالب : رانيا صبحى الجنى الأبر

اللوحة الزخرفية المجسمة السابعة عشر

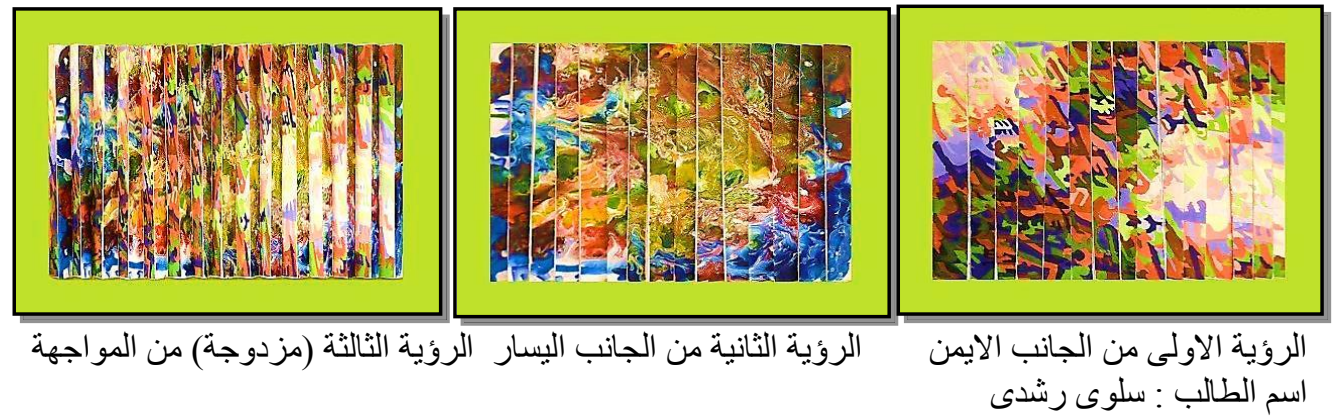

اللوحة الزخرفية المجسمة الثامنة عشر
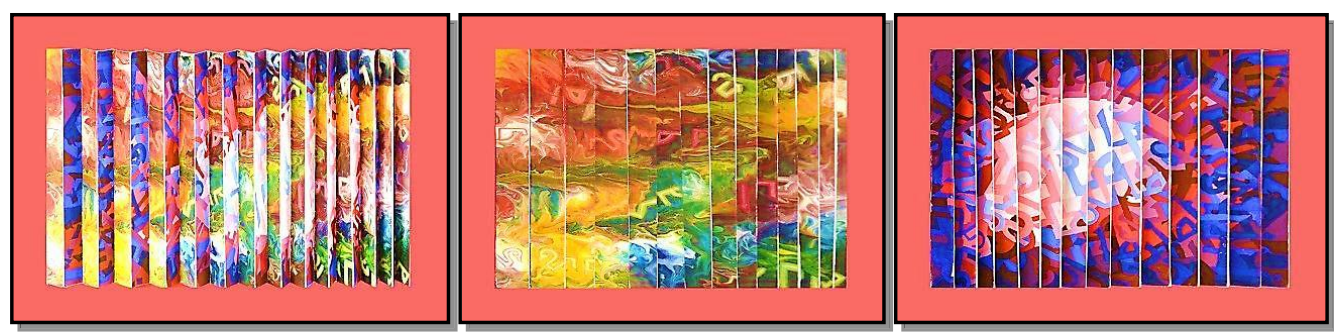

الرؤية الاولى من الجانب الايمن الرؤية الثانية من الجانب اليسار الرؤية الثالثة (مزدوجة) من المواجهة

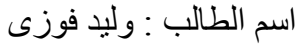




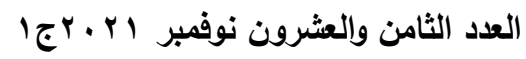

المجلة العلمبة لكلية التربية النوعية

اللوحة الزخرفية المجسمة التاسعة عشر

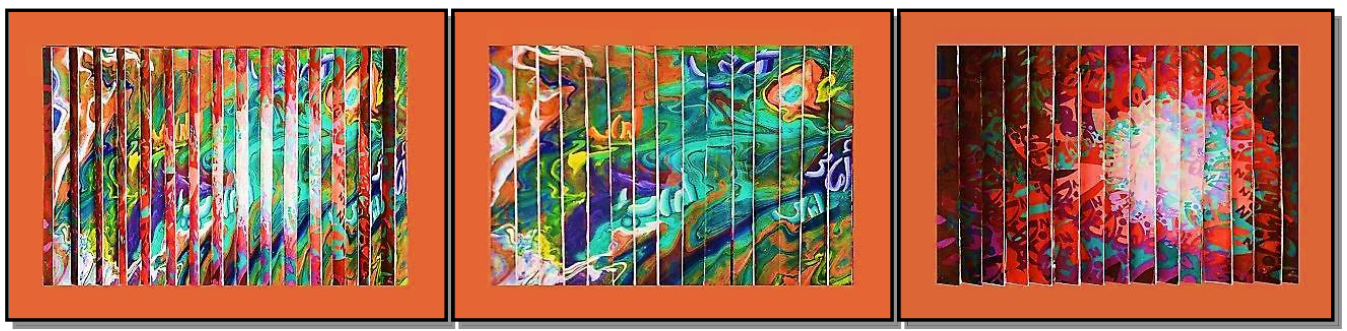

الرؤية الاولى من الجانب الايمن الرؤية الثانية من الجانب اليسار الرؤية الثالثة (مزدوجة) من المواجهة

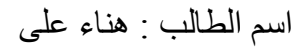

اللوحة الزخرفية المجسمة العشرون

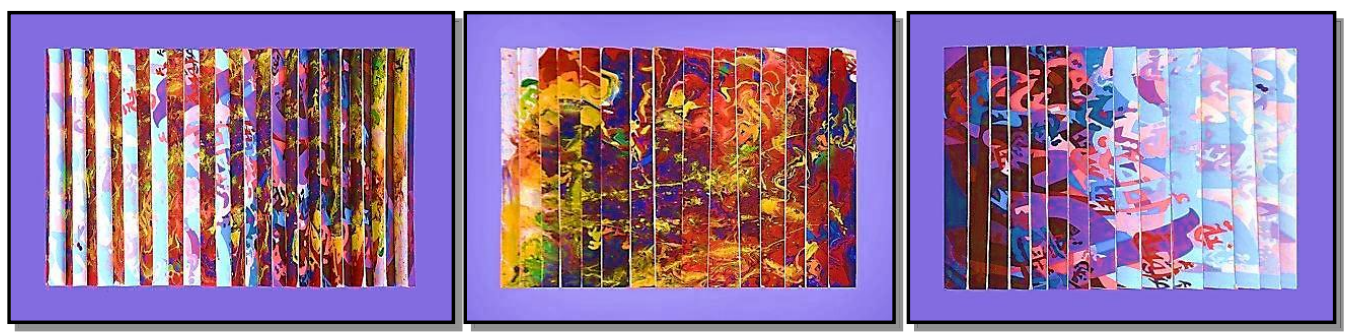

الرؤية الاولى من الجانب الايمن الرؤية الثانية من الجانب اليسار الرؤية الثالثة (مزدوجة) من المواجهة اسم الطالب : الانى خليل

اللوحة الزخرفية المجسمة الحادية والعشرون

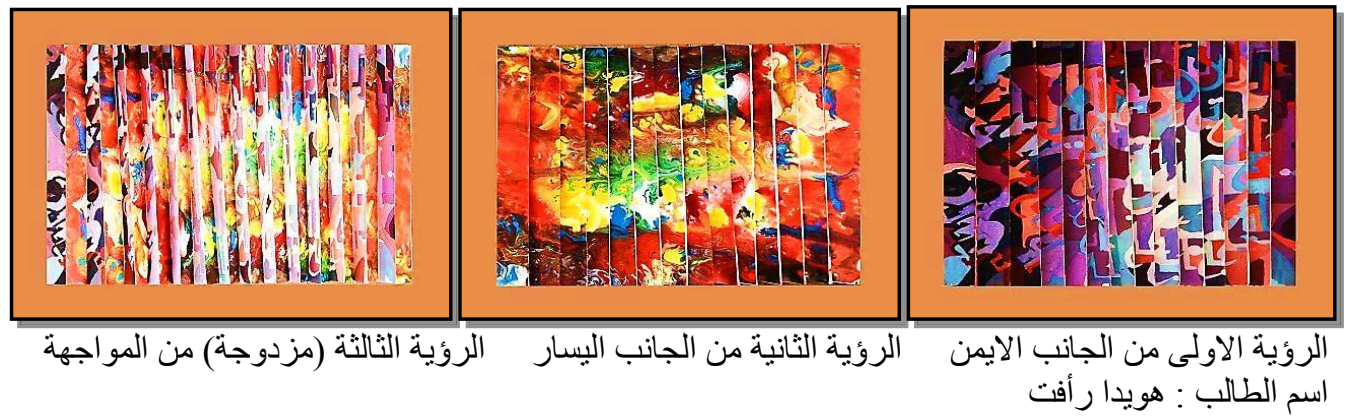

اللوحة الزخرفية المحسمة الثانسة والعشرون

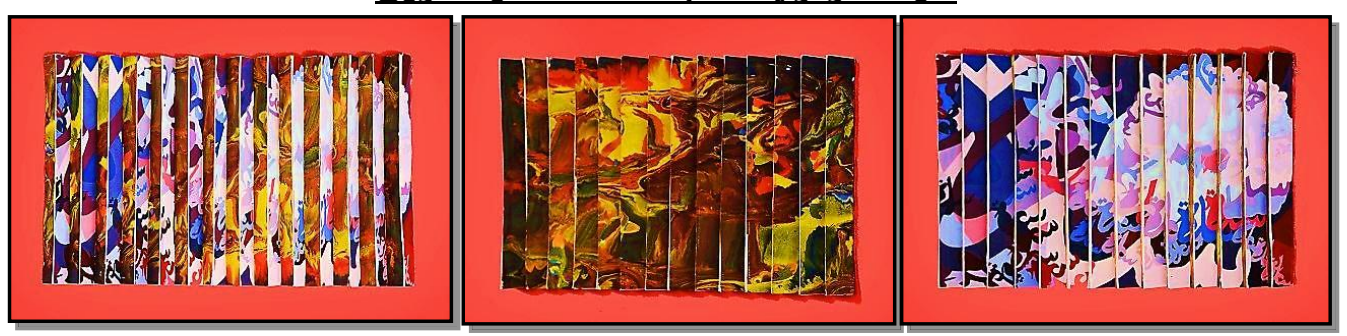

الرؤية الاولى من الجانب الايمن الرؤية الثانية من الجانب اليسار الرؤية الثالثة (مزدوجة) من المواجهة اسم الطالب : نيرة رضو الأن النان 
ا- - اتاحت الحركة الظاهربة الفرصة لتفاعل المتلقى وتعامله بإيجابية مع العمل التصميمى

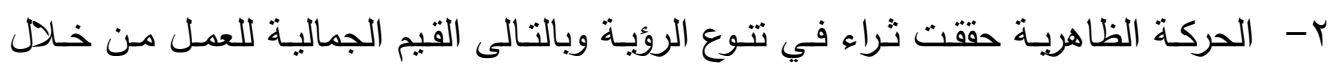
المتغيرات الثكلية للعمل التصميمى التهرئ ب- التصميمات المجسمة حقيقيا تتبح للمشـاهد اقامـة حوار مع العمل من خـلال ترجمة مجال

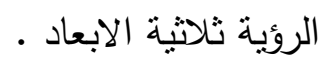
ع - اكدت التصميمات القائمة على الحركة الظاهربة للمشاهد على الفكر المعاصرة والمفاهيم الحديثة للتجريب في الفن •

0- الحركات الفنية من أهم المنابع المتجددة التى تمد مجالات التربية الفنية بأفكار معاصرة ج- الفن المعتمد على التفاعل بين المشاهد والعمل الفنى أخرجت المتلقى من حالة الجمود في الروئية الى التفاعل والمعايثة والمشاركة .

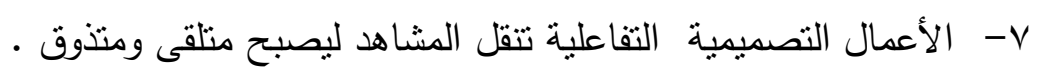
مما أدى إلى أن :

الحركة الظاهريـة للمتلقى ثثرى الروئة الجمالية للوحة الزخرفية المجسمة حقيقيا بمـا يحقق أهداف البحث ويثبث صحة فرضه . التوصبات :

في ضوء نتائج البحث الحالية قدم الباحث عددا من التوصيات التي قد تفيد التصميم : ا - أهمية ارتباط الفن بالفكر المعاصر والتجريب المستمر وانعكاس ذللك على مجالات الفن

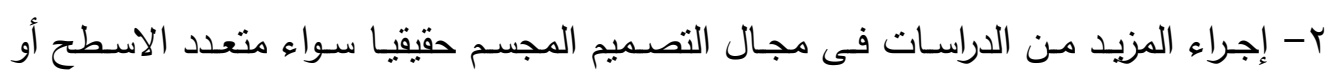

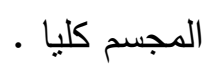

ب- دراسة لأنواع اخرى من الحركة الفعلية، ومدى ملائمتها لتحقق تصميميا .

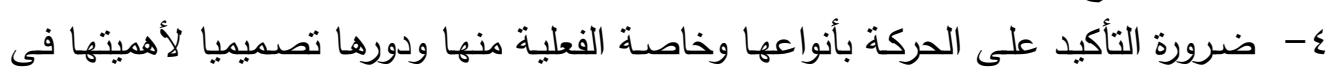
تحقيق الرسالة الفنية . - - ممكن الاستفادة من بعض التقنيات والحركات الفنية السـابقة للفن مثنل الخداع البصرى، وتوظيفها تصميميا بما يناسب فكر العصر وتحوله . 
ا- ابراهيم الحيسـن، 9 . . ب، التربيـة عن طربـق الفن، حفر في اليـات التلقى التشكيلى والجمـإلى،

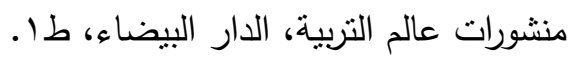

r- اسـماعيل شـوقى، 0 . . r. التصـميم عناصـره وأسسـه في الن التشـيلى، مكتبـة زهـراء الثـروق، القاهرة . ماهر

ץ- أميرة حلمي مطر، 919 (، مقدمة في علم الجمال وفلسفة الفن، الطبعة الأولى، دار المعارف، القاهرة .

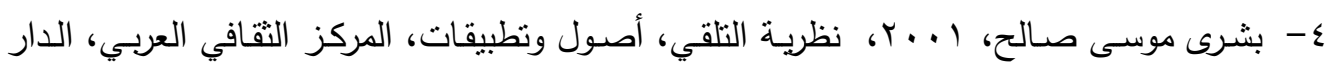

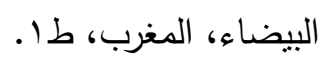

0- ريمون بايير، (19 19، ترجمة ميشال عاصي وميشال سليمان، تاريخ علم الجمال، بيروت لبنان • צ- حسنين شفيق، 9 . . r، التصميم الجرافيكى، دار فكر وفن، القاهرة .

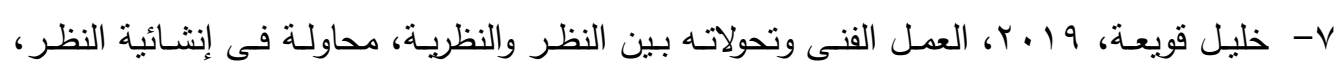

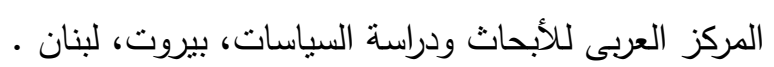

ثانيا : الرسائل والابحاث العلمية :

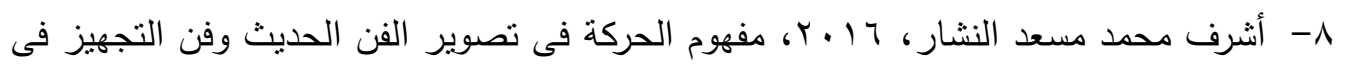

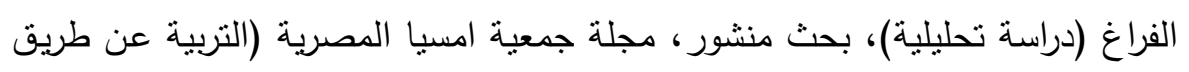

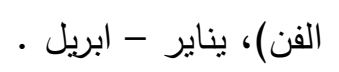

9- إيناس عبد العدل محمد، أيمن الصديق السمرى، 11 ـ ب، القيمة الجمالية والفلسفية لمفهوم العمل الجماعي من خلال ورشة عمل لفن التجهيز في الفراغ، بحث منشور بمجلة بحوث التربية

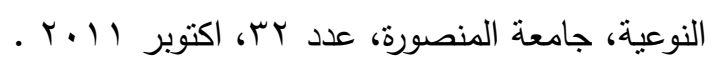

• ا-منى محمد شـاهين، 199 (9 مداخل لإضـافة البعد الثالث الحقيق كقيمة جماليـة للأعمال ثنائية الأبعاد فى مختارات من الفن المصرى الحديث والمعاصر ، رسالة ماجستير ، كلية التربية

$$
\text { • الفنية، جامعة حلوان }
$$

ا - منى محمود فراج ع 1 ـ ب، الكثف عن نظم الحركة الفعلية في عناصر الطبيعة واستخدامها في النشكيل المعدني، رسالة دكتوراه، غير منشورة، جامعه القاهرة .

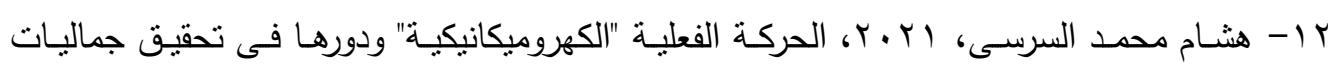
التصميم، بحث منشور ، مجلة البحوث في مجالات التربية النوعية، جامعة المنيا، المجلد

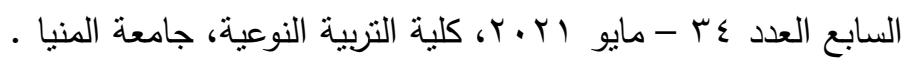


rا - هثام محمد السرسى، (Y . T، الديناميكية الابداعية لمعالجة الاشكال في التصميم كنشاط عقلي فكري في نطاق الحيز الحسي والبصري، بحث منشور، مجلة البحوث في مجالات التربية

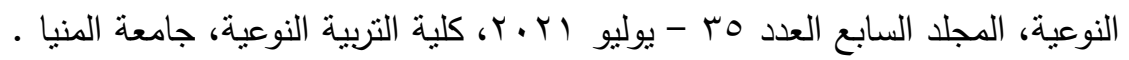

ع ا - نادر حمدي محمد حمدي، جلو9 (، فن الحركة الفعلية والإفادة منها في تدريس الفنون ، رسالة

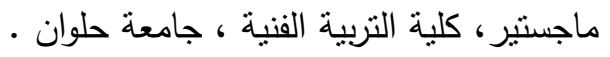

ثالثا : المراجع الأجنبية :

15- wucius, wong , 1977, principles of three dimensional design" van no strand Reinhold company, new York.

16- Claire Bishop,2005 Installation Art, Tate Publishing, London.

17- Dagobert D. Runes, Harry G. Schrickel : 1946, Encyclopedia of the Arts Hardcover January.

18- http://alwatan.com/details/312210

رابعا : مواقع الانترنت :

19- https://rommanmag.com/view/posts/postDetails?id=5534

20- http://elsada.net/116796

21- https://www.noorbook.com/\%D9\%83\%D8\%AA\%D8\%A7\%D8\%A8\%D9\%85\%D9\%82 \%D8\%AF\%D9\%85\%D9\%87\%D9\%81\%D9\%8A\%D\%B9\%D9\%84\%D9\%85\%D8\%A7 \%D9\%84\%D8\%AC\%D9\%85\%D8\%A7\%D9\%84\%D9\%88\%D9\%81\%D9\%84\%D8\%B3 \%D9\%81\%D9\%87\%D8\%A7\%D9\%84\%D9\%81\%D9\%86-pdf

22- https://foulabook.com/ar/book/\%D9\%85\%D8\%AF\%D8\%AE\%D9\%84\%D8\%A5\%D9\% 84\%D9\%89\%D8\%B9\%D9\%84\%D9\%85\%D8\%A7\%D9\%84\%D8\%AC\%D9\%85\%D8\% A7\%D9\%84\%D9\%88\%D9\%81\%D9\%84\%D8\%B3\%D9\%81\%D8\%A9\%D8\%A7\%D9\%84\%D9\%81\%D9\%86-pdf

23- https://mymodernmet.com/michael-murphy-president-obama-sculpture/

24- https://www.flickr.com/search/?text=YAACOV\%20AGAM

25- http://elbadryart.blogspot.com/2014/11/blog-post_28.html 